\title{
How Nascent Occupations Construct a Mandate: The Case of Service Designers' Ethos
}

\author{
Anne-Laure Fayard \\ Tandon School of Engineering, New York University \\ Ileana Stigliani \\ Imperial College Business School \\ London, UK \\ Beth Bechky \\ Stern Business School, New York University
}




\section{INTRODUCTION}

Occupations are fluid and evolving, often fighting among themselves for legitimacy and recognition during times of occupational change (Abbott 1988, Hughes 1958, Bucher and Strauss, 1961). In the course of contestation, task boundaries shift between multiple segments of occupations (Bucher 1962, 1988). Whether or not occupations are victorious in their battles for resources and jurisdiction, they all begin by establishing an occupational mandate for practicing (Hughes, 1958; Nelsen and Barley, 1997). This mandate, defined as the internally shared understanding and the externally perceived right to define "proper conduct," as well as values, beliefs, and ways of thinking (Hughes, 1958), provides the cultural underpinnings for an occupation's legitimacy. Thus, understanding how an occupational mandate is constructed even by those groups that might not cohere into solidly institutionalized occupations (Bucher, 1988: 141) - is vital to our knowled ge of occupational change. However, research on how new occupations gain such a mandate is still scant. This lacuna is particularly glaring given the current climate of burgeoning occupational change, in which new occupations surface while others fade, fuse together or redefine themselves.

Overall, the number of new and revised occupations documented in the U.S. Standard Occupational Classification system now comprises 974 categories, compared to the 503 occupational categories introduced in 1977. While opportunities for traditional employment are decreasing (Kalleberg, 2011), there is a proliferation of new and redefined occupations such as consultants (Werr and Styhre 2003), fundraisers, and web developers (Watson, 2013). In today's service economy where technology has become ubiquitous, new occupations cannot solely rely on skills and technical expertise as sources of differentiation. In the context of such changes, then, how do new occupations become legitimate? 
In this paper, we investigate what practitioners of a new occupation do to become recognized and construct an occupational mandate. We draw on an inductive qualitative study of the nascent occupation of service design, which uses design principles to help clients improve existing services or develop new ones in instances as varied as the facilitation of a more patient-focused healthcare experience to the design of a unique travel experience for airline customers (Mager 2004; Moritz 2005). Our findings enhance our understanding of the jurisdictional strategies of emerging occupations by showing how members of this occupation constructed their occupational mandate by demonstrating a specific ethos, i.e., particular values enacted through work practices. Our study highlights the important role played by values in the construction of an occupational mandate, in particular in cases of occupations where skills and expertise are not the main differentiator.

\section{Occupational transformation and the importance of an occupational mandate}

Occupations are in constant motion, frequently developing through shifts in task jurisdiction. They are composed of segments that continuously emerge, evolve, endure, and die (Bucher and Strauss, 1961; Strauss, 1978; Bazanger, 1990). Scholars taking an interactionist approach (Bucher and Strauss, 1961; Blumer, 1969; Strauss, 1978; Hall, 1972) emphasize "the social and interpersonal processes involved in the definition, maintenance and restructuring of social roles" (Rothman, 1979, p. 495). While they argue that triggers for occupational emergence are multiple - e.g., new technologies, a vacuum left by another occupation, the hiving off of "dirty work" (Bucher and Strauss, 1961; Bucher, 1988; Hughes, 1984; Zetka, 2003, 2011) - they show that fledgling occupations all go through a similar process of emergence. This process comprises several stages: finding like-minded colleagues, gaining an occupational mandate for activities, and legitimizing and solidifying an occupational jurisdiction (Bucher, 1988). 
Much research demonstrates how occupations solidify their jurisdiction through a variety of political, rhetorical, and expertise-related strategies. Occupations institutionalize, forming associations and leveraging their political power to control membership (Begun and Lippincott, 1987; Kronus, 1976; Halpern, 1992; Gross and Kieser, 2006; Kipping and Saint-Martin, 2005; McKenna, 2006). They make claims through abstract and formal knowledge (Abbott, 1988, Foucault, 1963; Hughes, 1984) and frame their expertise to convince audiences to grant them authority over task domains (Power, 1997; Lawrence, 2004; Gross and Kieser, 2006; Alvesson and Roberston, 2006).

Take one example of a well-studied occupation: Recent research on accountants suggests that political, rhetorical, and knowledge-based strategies have helped them expand their jurisdiction beyond traditional activities in their field. Lawrence (2004) documents how Canadian public accountants, who were not perceived as legitimate by other actors in the field (i.e., lawyers and engineers), framed a role for their occupation in the emerging field of environmental audits. For example, they created a professional association, which, although open to all, was dominated by accountants. The association (and the newsletter it published) was instrumental in defining what an environmental audit professional was and including in this definition people with accounting backgrounds. Accountants also used a quarterbacking strategy: Because of their experience with audits, accountants could take the lead in putting together project teams, connecting technical and legal professionals with clients, and thus become full members of the emerging occupational field. Similarly, Suddaby and Greenwood (2005) show how Big Five accounting firms tried to legitimize a new organizational form of multi-professional practice using rhetorical strategies aimed to appeal to the market. Accountants were able to solidify and expand their occupational jurisdiction through field-level political and framing moves. 
Although less studied than the solidification of jurisdiction, a key early phase in the occupational emergence process is the construction of an occupational mandate that is shared internally and recognized externally. Hughes (1984) defines an occupational mandate as both developing a shared understanding among members of an occupation and convincing others:

Generally, if the people in the occupation have any sense of identity and solidarity, they will . . c claim a mandate to define — not merely for themselves, but for others as wellproper conduct with respect to the matters that concern their work. They also seek to define and possibly succeed in defining, not merely proper conduct but even modes of thinking and belief that everyone individually and for the body social and politic with respect to some broad area of life which they believe to be in their occupational domain. (Italics in the original; p. 287)

Internally, members develop solidarity, which Bucher (1988:136) calls "discovering colleagueship," by forming around an impetus for change that triggers the emergence of a new occupation. These colleagues share a common culture, "a set of values, norms and perspectives that apply to but extend beyond work related matters" (Van Maanen and Barley, 1984: 287). These shared values, they believe, distinguish them from other occupations (Bucher, 1988; 1962; Bucher and Strauss, 1961).

Externally, when it comes to convincing others, the occupational mandate provides its members the license "to carry out certain activities rather different from those of other people and to do so in exchange for money, goods and services"(Hughes, 1984:287). The mandate lets occupational members define suitable answers to questions of practice within their occupational domain (Hughes, 1958; McMurray, 2011). Once a mandate is established, practitioners' sense of solidarity and identity gives them moral authority to claim that their ways of conduct and thinking related to the work are appropriate and relevant (McMurray, 2011:802). In both aspects of the mandate - internal and external - values infuse what is defined as "proper conduct," as well as modes of thinking and beliefs. 
Despite the need for a mandate to lay the ground work for legitimizing and solidifying an occupational jurisdiction, scholars have paid much less attention to how occupations construct an occupational mandate. Indeed, as stressed by a few scholars (Dingwall, 1983, Nelsen and Barley, 1997; Sherman, 2010), how occupations initially form and come to be recognized is a question largely omitted in the sociology of work. This omission has had two unfortunate consequences for our understanding of occupational change: we know little about early processes of occupational emergence, and we lack a deep understanding of the cultural and moral aspects of gaining legitimacy.

The first consequence reflects the emphasis of the current literature on investigating occupations which have already been institutionalized. The research describing both the triggers for occupational development and the tactics that occupations pursue to extend or change their jurisdiction are typically focused on occupations' later institutionalized stages when their main activities concern solidification, as can been seen in the studies of accounting described earlier. The focus on these later stages may be because gaining access to data about early stages is difficult (Nelsen and Barley, 1997). As a result, how new occupations in these early stages achieve social recognition by developing an occupational mandate with values and aspirations central for their work (Hughes, 1958) is underexplored. Our study aims to provide insights into early dynamics of emergence by describing how service designers construct their occupational mandate.

Furthermore, we know little about the role of values in the construction of an occupational mandate, because most studies do not focus on the interactions and work practices of occupational members. Previous studies of occupational jurisdiction have largely focused on the public face of occupations and their position in the larger institutional field. For instance, some 
scholars have tracked the dynamics of occupational power and control through analyses of public statements, political activities, and association formation (Kronus, 1976; Halpern, 1992). Others have investigated the rhetorical and representational strategies used by occupations to seek legitimacy (Power, 1997; Suddaby and Greenwood, 2005). By focusing on publicly available archival data scholars have explored the external and public aspects of the occupational mandate (e.g. obtaining jurisdictional monopoly or licensing requirements), but they have not been able to cast light on the internal ones (i.e. finding like-minded colleagues), and hence on the role of values.

For instance, in a recent study of management consulting firms, Kipping (2011) explained how management consulting companies relied on branding efforts (e.g. direct advertising, advertising for recruiting events, publishing books and carrying out high-exposure projects) to create an image of professionalism for the occupation. Using historical and contemporary studies of the management consulting industry and archival data from the Management Consultancies Association in the UK allowed him to capture public claims by the leading members of the occupation "to have assembled the true elite of the industry" (2011:531). However, this data does not uncover any of the values that management consultants might associate with this image of professionalism.

Because values are not observable per se but tend to be articulated through discourse during activity, to study values and their role in the construction of an occupational mandate we cannot rely on public statements, but we need to look at what members of occupations say and do, as well as the interactions between both. Rather than "conceptualiz[ing] occupational roles as merely a configuration of technical or intellectual operations within an overall economic division of labor" (Rothman, 1979: 495), we need to focus on the interaction work between different 
occupations, which involves a closer look at work practices in general.

Recent occupational scholarship in the interactionist tradition has explored how members of occupational groups construct their social worlds. These studies focus on work practices and the interaction order-i.e., patterns of situated action, interaction, and interpretation (Goffman, 1983) - to investigate cross-occupational dynamics in workplaces and occupations outside of traditional professions (e.g., Bechky, 2003; 2006; Nelsen and Barley, 1997; Zabusky and Barley, 1997). Because this approach explores how daily work practices are imbued with meaning, symbols, and values (Bechky, 2011), we believe it could help cast much needed light on the process of achieving an occupational mandate.

\section{Potential legitimizing strategies for nascent occupations: values and material practices}

Interactionist scholarship attends to how the workplace is constructed and negotiated through interaction among actors and suggests that much of our daily workplace activity is permeated by occupational values and identity (Strauss 1978, Hughes 1958). The entanglement of values and work practices has implications for the legitimacy of occupations. Some recent studies show how occupational members maintain legitimacy internally and externally by enacting their values in practices (Anteby, 2010; Barley, 1983). For instance, Anteby's study of commerce in cadavers (2010) highlights the importance of moral values and material distinctions in distinguishing different groups of practitioners. Practitioners in New York state who controlled the task jurisdiction adhered to a certain moral code in their practices, only accepting corpses that had been given with personal consent as opposed to those with consent of the family and "never removing fingernail polish from a cadaver so the medical students re member that this cadaver is somebody" (2010: 624). They viewed this material treatment of cadavers and trading partners as a legitimizing moral distinction and used this practice to prevent other practitioners from gaining 
a foothold in the field. Similarly, Barley (1983) illustrates the role of value-laden practices in legitimizing the work of funeral home directors. Through various practices-preparing the corpse to give it a lifelike appearance, organizing chapels to create a homey feeling, and avoiding noises when removing the body from a personal home-funeral directors aimed to make funeral scenes "natural" to the family and friends and to diminish the negative emotions associated with death.

Given that values enacted through practices are useful in maintaining occupational legitimacy, we suggest that they may also be a means for carving a mandate during early occupational emergence. Indeed, a couple of examples of professionalization suggest that occupations have used this strategy. For instance, Nelsen and Barley (1997), in their comparative study of voluntary and paid emergency medical technicians (EMTs), demonstrate how distinctive ways of talking and acting helped persuade relevant audiences of the legitimacy of paid EMT work. For example, their demeanor when interacting with patients - turning off the radio during the drive to the hospital, sitting quietly by the patient at the hospital, filling in written reports-aimed to create a sense of professionalism that contrasted with the supposed amateurism of volunteers. Similarly, Arndt and Bigelow (2005) describe the professionalization of the occupation of hospital superintendents into hospital administrators. In the early 1900s, the male-dominated professional association of hospital administrators succeeded in masculinizing the occupation, which at the time was mostly female. They did so by forging a new set of male-gendered values and work practices associated with the position: The work was reconceptualized and enacted as rational and efficient rather than charitable and benevolent.

Inspired by these studies, we highlight the role that both values and material practices play in the construction of an occupational mandate for emergent occupations. We show that values are 
important for establishing legitimacy, particularly when they are demonstrably intertwined with material practices. In the case of service designers, their ethos (i.e., their values enacted through material practices) was central to the construction of an occupational mandate. Service designers differentiated themselves from traditional designers (with whom they shared some work practices) and other occupations, like management consultants and marketers, who worked on similar projects (e.g., redesigning brands, creating better customer experiences). Instead of relying on a specific set of skills or mastering technology to create distinction, service designers distinguished themselves through their ethos, i.e., a certain attitude enacted in a special way of doing things.

\section{METHODS}

This project began in late 2009 as an interview-based study of service design that included complementary observation and archival data collection. It expanded into a five-year project in which we ${ }^{1}$ continued our involvement with the service design community on a regular basis. We participated in various events about service design that were organized by service designers, engaging in observations and impromptu conversations. We also developed relationships with a few service designers with whom we regularly had informal conversations about their work. We cultivated these relationships so we could be sensitive to the dynamics of the occupation, share with them our provisional interpretations, and get feedback. Lastly, we read Touchpoint, the official professional journal on service design, and followed the websites of many service design consultancies. We also read newsletters sent by some of the major service design consultancies and participated in online groups, such as the LinkedIn service design group, to monitor conversations among service designers and their views about their work and others' work. This ongoing data collection complemented the more focused and intensive data collection that

\footnotetext{
${ }^{1}$ The first 2 authors collected the data; the third author was actively engaged in the analysis phase.
} 
occurred in three main rounds over five years and allowed us to develop a thorough understanding of the occupation as well as to collect many stories related to service-design projects.

\section{Research setting}

Service design is an emerging occupation in which practitioners aim to understand customers (also called users ${ }^{2}$ ), organizations, and markets; develop new or improved services and customer experiences; translate them into feasible solutions; and then help organizations implement them (Mager 2004; Moritz 2005; Kimbell, 2011). Examples of service-design projects include designing travellers' experience with an airline (from booking to check-in, travel, and arrival), the patient's experience in an emergency room, and a brand and its associated strategy. These projects seek to connect the needs of customers with the capabilities of service providers, envisioning the service as enacted in time and space through various touchpoints, the tangible elements that make up the experience of using a certain service. ${ }^{3}$

The historical roots of service design date back to the academic activities and publications of the 1980s and 1990s (e.g., Shostack, 1984; Hollins and Hollins, 1991), when the idea of designing services began to be referenced and the concept of a service blueprint (a specific tool for designing services) arose. Then, in 1996, IDEO, an international design and innovation consultancy, began to develop a strategy for a company that offered new, high-speed rail services. Although they were originally hired to redesign the seats, the IDEO team quickly realized that the train experience was more than just seating. It was a journey that started as soon as the passengers began searching for trains and fares and ended after they left the train at their

\footnotetext{
${ }^{2}$ We use "customers" or "users" interchangeably, in keeping with our informants' use of the terms.

${ }^{3}$ Touchpoints include spaces, objects, people, and interactions and take many forms: advertising cards, bills, retail shops, call centers, and customer representatives, as well as web, mobile phone, and PC interfaces.
} 
destination (Brown, 2009). Although no one spoke of service design at the time, several of our informants referred to that project as the first service design project.

Yet while its early seeds may have taken root in academia and practice, service design remained underground until 2001, when the expression "service design" started being used explicitly by Live Work, then a new, London-based company. Its founders had left their previous jobs in interaction design to work on more strategic, broader projects than designing websites. According to them, the term "service design" was born from their reflection on their work: They were designers whose focus was on services so "service design" seemed an obvious fit. Over time a burgeoning group of practitioners who called themselves "service designers" began working on service-design projects. Identifying as generalists rather than specialists, they sought to name the tasks, practices, tools, and techniques they required to design services. Our informants stressed that they borrowed tools and techniques from several other occupations, such as product design, branding, marketing, and theater (See the appendix for a detailed list).

Initially, service design included only a few consultancies such as Live Work and Engine Service Design (which, according to our informants, were the first two service design consultancies in London) and a handful of individuals working as freelancers. Service design has since experienced rapid growth: Several European design schools have begun offering courses in it, as have several in the US. ${ }^{4}$ New service design consultancies have been founded (initially in the UK but now worldwide, thus creating new communities of practitioners across Europe, the United States, and Asia Pacific), and some of the larger international design consultancies have

\footnotetext{
${ }^{4}$ Examples include the Köln International School of Design, Linkoping's University, Domus Academy, and the Royal College of Art. SCAD in Savannah was the first university in the United States to offer bachelor's and master's programs in service design. Other schools like Parsons New School and ITT Design Institute offer servicedesign courses. Moreover, over time management scholars have been paying increasing attention to service design and service innovation (Mager, 2004; Moritz, 2005; Vargo and Lusch, 2004; Vargo, Maglio and Akaka, 2008; Lusch and Nambisan, 2015).
} 
started explicitly featuring service design among their offerings and practices. In 2004, the Service Design Network (SDN) was created with the goal of becoming an international network of academics, practitioners, and businesses promoting the development and spread of knowledge and expertise in the field of service design; it became a nonprofit four years later. In 2009, SDN launched a journal, Touchpoint, which is published three times a year and "provides a written record of the ongoing discussions of the service design community. It aims at facilitating a forum to debate, share, advance, and codify the field of service design and its practices. " ${ }^{5}$ In summer 2010, the UK newspaper The Guardian published a supplement on service design featuring a series of case studies in various domains, many of them involving our informants.

The number of service design related projects has continued to grow since the first projects done by our informants and most of the consultancies and consultants we interviewed at the origins of this study are still in business today. There are also signs that service design has developed an occupational foothold and they are seen as distinct. In December 2015 Forrester Research released a report entitled "Vendor Landscape: Service Design Agency Overview" based on a survey of 70 service design agencies. They argued that although service design is far from being a homogeneous discipline, the service design provider landscape has changed in the last two years as it includes now not only small service design agencies concentrated in Europe, but also "full-service design agencies and management consultancies claiming service design among their offerings." Indeed, in the last few years management consultancies like Accenture, Deloitte, and EY have acquired service design consultancies (respectively Fjord, Doblin, and Seren Partners) while explicitly keeping them independent, thus signaling that service design provides a unique approach to the design of services. Yet, despite having gained an occupational foothold, all our informants still refer to service design as "emerging" or in "its infancy."

\footnotetext{
${ }^{5}$ http://www.service-design-network.org/read/touchpoint/
} 
Practitioners describe their occupation as being in a constant state of flux: "What we do is evolving. There can be very little argument that service design is finding itself in some odd places these days, from working to reduce crime, to supporting disarmament processes, to actively shaping public policy. We are finding ourselves enacting new roles and slipping over the boundaries and borders of traditional disciplines."

\section{Data Collection}

Our data collection combined open-ended interviews, non-participant observations, and archival data.

Interviews. We were interested in the emergence of service design as a field, and this consideration shaped the composition of our sample of informants (Glaser and Strauss 1967; Locke 2001). Over a period of nearly five years, we conducted a total of fifty-five ethnographic interviews (Spradley, 1979) in three rounds in order to progressively support our emerging interpretations.

During the first round (February-August 2010), we conducted twenty-five interviews ${ }^{7}$. We focused our attention on informants who had played a prominent role in the emergence of service design (i.e. the founders of the first service design consultancies in the Greater London area), and then, using snowball sampling (Lincoln \& Guba, 1985) we progressively selected additional informants (service designers working in consultancies or as freelancers) involved in the occupation's emergence and located in the same geographical area (service design as a field originated in the greater London area).

\footnotetext{
${ }^{6}$ Touchpoint $3 \# 1$ - Leaning, Changing, Growing. (Kindle Location 164). Service Design Network.

${ }^{7} \mathrm{We}$ conducted twenty-five interviews with twenty-one informants. Of the twenty-one, four were interviewed twice so that we could discuss in more detail some of the insights that resulted from the first interview.
} 
Our second round (May 2012 - August 2012), which involved sixteen interviews, aimed at gaining a better understanding of our emerging interpretations about how service designers were constructing their mandate (with specific reference to values and practices). Having become aware that the occupation was expanding in other geographical areas, we interviewed practitioners located in New York (4), New Zealand (3) and Australia (2) as well as in London (4). Some of the informants we talked to in the first round gave us names of practitioners in these areas and we selected those who had had a central role in the emergence of service design in those areas. Moreover, during some of the interviews conducted in the first round, informants referred to the fact that some design schools had started offering programs on service design. Considering this an important aspect of the development of the occupation, we also talked to three academics teaching service design-related topics. Finally, we interviewed the project manager for an airline service design project, as well as the lead designer on that project.

Finally, as occupational emergence also involves external recognition, we conducted a third round of interviews (September-December 2014) both to provide a more nuanced explanation of the service design process and of its practices and to gain the clients' perspective on the way service designers work. We asked some of our key informants for additional interviews, during which they shared with us additional examples of projects they had worked on. They also provided us with names of clients they had worked with, whom we then interviewed. Some of these clients referred us to management consultants who had collaborated with service designers on some big projects, and we also interviewed them. We conducted nine focused interviews with seven clients and two management consultants to better understand their perceptions about how service designers work in comparison with other occupations. In order to further round out our interpretations of how the occupation had evolved since our project's 
launch, we also interviewed a service designer and re-interviewed two service designers we had spoken to in previous phases.

Interviews lasted between one to two hours and were recorded and transcribed. The first two rounds of interviews followed an open-ended protocol covering the background (education and previous experience) of the informants, their role in the development of the occupation of service design, their definition of the field, what it meant to work as service designers, with detailed description of specific projects. The third round of interviews was aimed at capturing the clients and management consultants' perceptions about service designers' work and at enriching our developing interpretations. We refer here to informants and service design consultancies by pseudonym to guarantee anonymity. Table 1 provides a summary of the three rounds of interviews.

Insert Table 1 about here

Observations. When visiting service designers on company premises, we were often offered a tour of the work space. After each visit, we recorded field notes of our observations about the physical setting and the tools they used. We attended six meetings organized by some of our informants' service design consultancies, including brainstorming sessions, internal knowledgesharing meetings, and other work-related meetings. In the last few years, we also participated in conferences (3), talks (12), and workshops (9) on service design organized by the Service Design Network (SDN) as well as by service designers. We attended major service design events such as the Global Service Jam, "a non-profit volunteer activity organized by an informal network of service design aficionados, who all share a common passion for growing the field of service 
design and customer experience. ${ }^{\circ}$ We also went to several social events such as "Service Design Thinks and Drinks" or "Service Design Salon" hosted by service designers in London and New York. Finally, the first author has followed the New York chapter of the SDN since its inception, attending events and informally meeting with some of its founders. These activities helped us establish trust with informants and provided us with a rich understanding of the service design community because practitioners often shared stories about their projects and client relationships.

Archival Data. We conducted extensive reviews of the websites of the service design consultancies for which our informants worked, the Service Design Network (SDN), and the Service Design Group on LinkedIn. We read all issues (April 2009-December 2014) of Touchpoint, the international journal of service design published by the SDN, and many service designers' blogs and personal websites, where numerous online discussions and debates about the nature of service design took place. In addition, our informants shared press articles, corporate brochures, books, pamphlets, and internal and external presentations intended for specific projects. Archival data was used to triangulate and integrate the evidence derived from interviews and observations (Glaser \& Strauss 1967:65). Table 2 provides detailed information on the data sources and their use in data analysis.

Insert Table 2 about here

\section{Data Analysis}

In analyzing the data, we used an inductive approach built on constant comparison and contrast (Glaser and Strauss 1967, Miles and Huberman, 1994; Strauss and Corbin 1990). We used interview transcripts and field notes from observations as primary data for the analysis and archival data to support and refine emerging themes. We coded independently and then

\footnotetext{
${ }^{8} \mathrm{http}: / /$ planet.globalservicejam.org/content/about
} 
compared and discussed the recurring themes, fine-tuning our interpretations and occasionally recoding some of the data.

Initially, the analysis consisted of multiple readings of the interview transcripts and field notes. From interviews with early practitioners of service design, a narrative about their frustration vis-à-vis the status quo surfaced: Their work did not allow them to integrate their creative skills, and they wanted to be more "strategic." They also stressed the need to create a community of like-minded others, especially because there was little outside recognition of the term "service design," which was unclear to other designers, potential clients, and competitors. This sparked our interest in understanding the debut of service design as an occupation. We then collated all portions of the transcripts that contained passages in which service designers talked about themselves and their peers, either stressing the similarities between like-minded people or highlighting their differences from other occupations. We included quotes containing expressions of differences from other occupations, such as management consultants and marketers, as comparisons with the two occupations arose frequently. When talking about being designers, our informants would often refer to design practices such as observing, shadowing, developing personas, using visuals, and developing various types of prototypes. Our observations confirmed the importance of material work practices for service designers. We looked for similarities among the material practices that characterized the way service designers worked. Three main practices surfaced: doing research, visualizing, and prototyping.

At this point, we also noted that, when discussing their practices, service designers, instead of arguing for the novelty of their tools and practices, acknowledged that they borrowed from other disciplines. What made service designers different, they argued, was how they worked, which influenced what they did. More specifically, many informants highlighted the importance of their 
values, which were exhibited in their work practices. Several of them referred to these values enacted in practice as the service designers' ethos. These insights prompted us to reanalyze our data more closely to better understand the role of service designers' values in constructing their occupational mandate. We identified three main values: taking a holistic approach, being empathetic and co-creating. Clients and consultants we interviewed mentioned similar values when describing service designers. We also reviewed our archival data to see if these values and material work practices appeared. Both in the LinkedIn discussions and Touchpoint issues values and practices were mentioned as a key differentiator in the way service designers worked.

While our analysis showed both the importance of values and practices in defining the work of service designers, we also realized that it was a challenging, if not impossible, task to clearly separate them. Indeed, it seemed that not only could we not distinguish them, but they were in fact deeply intertwined. Moreover, these intertwined values and practices were the way in which service designers distinguished their newly emerging occupation from others in the field.

\section{ENACTING A NEW ETHOS THROUGH MATERIAL WORK PRACTICES}

Our informants reported that established occupations (e.g., designers, management and marketing consultants) and potential clients (i.e., service providers) did not initially perceive and recognize them as members of a new occupation. Thus, they had to construct an occupational mandate in order to carve out a niche for their occupation and to differentiate it from others. This is well articulated in one of the first Touchpoint issues:

The challenge for us is how to work our way into positions where we have, and are seen to have, something genuinely different and useful to offer alongside a range of professionals and tried and tested approaches to problem solving and innovation. ${ }^{9}$

Indeed, members of an occupational community usually define their belonging by identifying with those who are similar and by drawing distinctions from those who are different and do not

\footnotetext{
${ }^{9}$ Touchpoint $1 \# 3$ - Beyond Basics (Kindle Locations 569-571). Service Design Network.
} 
belong to their occupation (Van Maanen and Barley 1984; Weber 1968). This need to distinguish themselves from other occupations by a certain way of doing things was emphasized in the first

\section{Touchpoint:}

As a discipline, Service Design occupies a new space between design and marketing agencies, management consultancies and research agencies, exemplifying the virtues of people-centeredness and co-creation as fundamental processes. ${ }^{10}$

As this quote suggests and as reported by our informants, service designers differentiated themselves vis-à-vis two types of "others": designers and non-designers, such as management consultants and marketers. They did so by referring to their ethos, composed of values enacted through material work practices.

\section{Ethos as the main differentiator between traditional designers and management consultants}

Our informants firmly grounded their work in design work practices, called themselves designers rather than consultants, and referred to their workplace as the studio rather than the office. However, they clarified that the difference between them and other non-designers resided not only in design work practices, which other designers also used and that management consultants and advertisers could always learn, but in 'the attitude that [service designers] bring in, what they value, [which] is different from agencies and marketing agencies, management consultancies," as Victor, senior service designer at Innovation, noted. This attitude was explicitly mentioned by one founder of a service design consultancy in an article posted on his firm's website and featured in its newsletter. He defined service design as "an ethos, methods and tool set that enables an organization or business to get a handle on how they can better engage customers and deliver value to them."

\footnotetext{
${ }^{10}$ Touchpoint $1 \# 1$ - What is Service Design? (Kindle Locations 309-310). Service Design Network.
} 
In other words, it was service designers' ethos - a term our informants used to define their work and highlight its distinctiveness - that really differentiated them from other occupations. According to the Oxford dictionary, ethos is "the characteristic spirit of a culture, era, or community as manifested in its attitudes and aspirations," i.e., the underlying sentiment that informs the values and practices of a group or society. Service designers' ethos encompassed both their values, which influenced their approach to work, and the work practices through which they enacted their values. Thus, values and work practices informed each other: while values defined how service designers worked, it was only in and through practice that values were performed.

When describing what it meant to be and work as service designers, our informants mentioned three specific values at the core of their ethos: holism, empathy, and co-creation. Taking a holistic approach to services involved adopting a system view and understanding the multiple actors involved in time and space rather focusing on developing just an interface or product. Being empathetic to all stakeholders meant showing empathy for all the people they designed for, both users and service providers. Finally, their commitment to co-creating meant that designers worked as facilitators of the design process; they did not design independently but co-created with a team that included users and clients. These values were what made service designers' work and the way they performed it distinctive and difficult to replicate.

These values were not only claimed by service designers, but they also infused three material practices central to service designers' work: conducting design research (collecting evidence by using diaries, pictures, sketches, and developing personas), visualizing (using sketches, journeys, maps, blueprints, Legos, and Playmobils), and prototyping (using paper, cardboard, 
bodystorming, ${ }^{11}$ and role playing). Service designers signaled the importance of these practices explicitly: most service design consultancies included in our study had a dedicated page on their website presenting the tools they used, thus making a clear statement to potential clients. Moreover, many articles in Touchpoint and conversations on the Service Design LinkedIn group emphasized these three material work practices as central to service design.

The differentiating character of the ethos (i.e., values enacted through work practices) was emphasized by service designers we interviewed and confirmed by their clients. Clients noted that this ethos made service designers' approach very distinctive even when working on projects similar to those undertaken by management consultants and marketers. Service designers' ethos thus proved crucial in defining their occupational mandate and in differentiating them from whom they perceived to be service design's competing occupations, i.e., traditional designers and non-designers.

\section{Service designers and traditional designers}

Traditional types of designers ${ }^{12}$ and their work practices represented an important reference and point of departure for service designers. Although originally trained as designers, many of our informants decided to migrate towards the design of services because of a deep dissatisfaction with their jobs, which they felt were too routinized and not creative enough, and because of a desire to be involved upstream in the innovation process. Nick, cofounder of Strategic Design, one of the first service design consultancies, summarized this need to be more creative and strategic:

11 Bodystorming is a technique of idea generation that involves experiencing a situation physically (usually involving artifacts and ideas).

${ }^{12}$ Traditional types of designers were referred to by our informants as a single category, encompassing designers trained in well-established design disciplines, such as product, industrial, interaction, or graphic design. 
We set out with a frustration about traditional design. We wanted to do things more strategically. We wanted to help organizations decide what to do and how to do it . . using creative tools and designerly approaches.

For many this move was not easy. They reported a lack of recognition due to two characteristics of service design: its ambiguity and its multidisciplinarity. Because services are intangible, it is not obvious how they can be designed. In fact, this is why the first self-appointed service designers were rejected by their peers as designers: They were no longer traditional designers because they did not design tangible products - material or digital. Moreover, in order to design services, practitioners needed skills from multiple fields, which made it difficult for them to name their occupation. Thus, early practitioners of service design did not have a good way to define their work, and some of our informants admitted that for a while they stopped calling themselves "designers" and tried different names. Yet they ended up calling themselves designers again because, as Erick, cofounder of Strategic Design, put it, "it has to be design. It has to be - what else can it be? You can't call it anything else."

However, while defining themselves as designers when it came to their practices (design research, visualizing, prototyping) and to some of their values (empathy in particular; and cocreation to a certain extent), our informants claimed that they differed from traditional designers in two ways. First, they saw their role as a facilitator of the co-creation process rather than the figure of the solo designer. Second, their aspirations, they noted, were closer to management consultants and marketers. In particular, going beyond implementation and moving "upstream" to be involved in "writing the brief" were mentioned as the main motivations for their transition to service design. These aspirations coalesced in an important value of their ethos, being holistic. Service designers and non-designers

When comparing themselves with non-design occupations such as management consultancies and advertising and marketing agencies, service designers conceded that they 
worked in the same domain, i.e., helping clients to develop new or better services, brand experiences or strategies. In fact, several informants explicitly stated that management consultants and, in some cases, advertising and marketing agencies were their competition. They simultaneously emphasized how specific practices made their work distinctive. As Victor, senior service designer at Innovation, explained: "I think we'd say we're different from the competition, which is usually management consultancies, because we use design [practices]." Beyond design practices, though, which could always be learned and mimicked, service designers claimed that their values, which were exhibited in their ways of working, were a key differentiator from management consultants and marketers.

The clients we interviewed consistently highlighted differences between service designers and management consultants, which reflected the differentiating role of service designers' ethos. They made distinctions not only in terms of the service designers' material practices - design research, prototyping and visualizing - but also in terms of service designers' general approach to work, which was inspired by their values. Zeynep, senior strate gy and business developer in a civil and social organization in London, stressed how service designers' work differed from that of the management consultants she had worked with on other projects:

There's something very different about service designers, their methodology and their approach to work that is, I think, far more genuine about trying to actually design the service . . . So I would never again bid for any funding without engaging a service designer or a service design agency to do kind of a bottom-up design of the service.

We found that service designers re-interpreted these values in relationship to each other. In particular, the aspiration to move upstream in the innovation process led service designers to embrace holism as a central value, interpreted as going beyond the design of single touchpoints for customers to encompass the entire system of touchpoints and actors involved in the creation and delivery of services. However, as noted before, they also perceived themselves as designers, 
and considered this as a key differentiator vis-à-vis their competition in their new scope of work (i.e. management consultants and marketers). Therefore, they also embraced design values, such as empathy and co-creation, but reinterpreted them in light of their holistic perspective. Hence, their attachment to holism as a value led them to broaden their interpretation of empathy and of co-creation in order to include not only the users but also clients and other stakeholders. In turn, holism was not simply conceived of as a strategic or system perspective on a service, but was imbued with a deep understanding of and empathy for different actors'contexts, practices and needs. It also implied that all stakeholders co-created the service, not only during the design phase, but also when the service was enacted.

In the remainder of this section, we present the three values of service designers and describe how they are enacted through material practices. Service designers used practices of design research, visualization and prototyping in specific ways (inspired by their values) that demonstrate their ethos. We then explain how enacting their ethos helped differentiate service designers from those in other occupations. The values and the material work practices that make up service designers' ethos should be seen as neither exhaustive nor exclusive. They are discussed independently for analytic convenience only. In practice, they overlap and interact in service designers' work and, thus, in the construction of their occupational mandate. In Table 3, we show additional evidence to support our interpretations.

Insert Table 3 about here

\section{Taking a holistic approach to service}

Service designers understood services as taking place over time and space among multiple actors and touchpoints. Therefore, instead of focusing on a specific aspect of a project, as traditional product or graphic designers do, service designers looked at a project from multiple 
angles and at different moments in time. They considered approaching service from a holistic perspective (sometimes referred to as understanding the "big picture" or taking a "system view") to be a central value that inspired their approach to work, specifically allowing them to engage with clients as strategists. Shifting from a product or interface focus to a strategic one was the motivation many of our informants claimed for becoming involved in service design. ${ }^{13}$ This holistic view of service implied that service designers needed to understand the whole contextremembering the service provider and the different stakeholders involved, as Nick, cofounder of Strategic Design, explained:

As a service designer you try to understand what the big picture is, and you try to help organizations join the dots up and stitch things together and help them to understand how they bring their resources to bear to deliver the right thing.

We found that holism was enacted by service designers through all three material practices: design research, visualization, and prototyping. For example, while working with the UK National Health System (NHS) on a project tailored to kids who have Attention Deficit Hyperactivity Disorder (ADHD), service designers at Sustain and Grow realized during the research phase that this was not only a medical problem, but also a school and parental problem. They identified and talked to the different groups of people who usually interacted with these children: parents, teachers, psychologists, and mental health professionals. The holistic approach adopted in the research phase (in conjunction with an empathic understanding of each actor) led the service design team to broaden the scope of the intended service. Indeed, although the UK NHS was initially focused on targeting only a very small number of children affected by ADHD, the team realized, after talking to different stakeholders, that the service could be used by a larger

\footnotetext{
${ }^{13}$ Similarly, several Touchpoint articles highlight how service design practice has developed at a strategic level: "Over the years, service design has moved beyond the interface and it now systematically touches strategic, organizational and cultural issues." Touchpoint 1\#3 - Beyond Basics (Kindle Locations 158-160). Service Design Network. Kindle Edition.
} 
group of children. These children, although not diagnosed with ADHD, still had behavioral issues that required support; they could benefit from the new service. Design research unveiled the entire service system: It mapped the interactions between providers and users of the service and highlighted the connections between different touchpoints where the interactions between customers and service providers might take place.

Visualizing, especially by creating customer journeys and service blueprints based on findings from design research, was key in helping nurture a holistic view of the service as a system and thus envision a better service - be it an insurance policy, airport check-in, or experience at a bank or train (see Figures 3 and 4 for examples). When recounting a project about a new train experience, Stephen, cofounder of Future, recalled how his team developed the "seamless journey" as a visual framework to illustrate what the new service would look and feel like. This framework visually mapped "all of the bits of their service, all of their components, all of the elements, all the people that you are delivering the service to." It became a powerful communication tool that helped all the client's departments realize the interdependencies between their activities in actually delivering the service and identifying organizational changes that needed to be made so this "seamless journey" could be offered. The visualizing practice differentiated service designers from marketers and management consultants who mostly used PowerPoint presentations, explained Shak, one of the clients we interviewed:

We were always very impressed by the visual tools they were using to represent the complexity of the services. So that was a new element to the way that we've worked with consultants in the past because they're anything but visual. Whereas I think service designers obviously presented things in very engaging ways and had lots of tools and techniques for generating conversations and thinking.

Visualizing went hand in hand with prototyping, which allowed service designers to test and determine different aspects of a service as well as the roles of all stakeholders involved. Service designers used prototyping to represent various parts of the system and to help clarify the 
connection between them. This is well illustrated by a new car-sharing experience project developed by Sustain and Grow. Prototyping for it was particularly useful for streamlining the process and coordinating between users, the car-sharing company, and the driving and vehicle license department. During the research phase, service designers discovered that users of the service either dropped out at the sign-in phase or needed customer support because the process was difficult to understand. Hence, Sustain and Grow prototyped a small booklet to help customers during the sign- up phase. They made several versions to test different steps. Based on users' feedback, Sustain and Grow service designers eventually redesigned the process in four simple steps-book, unlock, enter PIN, drive-that were visually presented in a small booklet left in all cars and available on the website. Through prototyping, service designers also found that a booklet with four steps was more efficient than a call-supported sign-up process. Prototyping in this case allowed Sustain and Grow to design a solution that was user-friendly and more efficient for the company. The process was easier for customers and it simplified implementation for the client who would not need to be on a call with each new customer.

Our informants also emphasized the importance of taking a holistic approach as a key differentiator between a design "only" and service design approach to developing services. For example, designers focus on developing a touchpoint - the seats on a train or plane, a check-in booth, a website interface to a bank or public agency — while service designers see each of these touchpoints as part of a bigger service system involving various actors interacting to produce the service. The holistic approach also distinguished service designers from management consultants and marketers who were usually not interested in the end-to-end design of a service and its implementation. Ricardo, a client of Sustain and Grow, who also had a background in 
management consulting, emphasized the specificity of service designer's ethos. In particular, he credited service designers' holistic approach as differentiating how they worked:

They were much broader, wider, and more holistic than management consultants would normally and naturally do; their net is wider and bigger in terms of their starting point and about how much do you cope with things and how much you consult with the different stakeholders.

Ricardo stresses here the importance of service designers' holistic approach while also suggesting that this approach worked specifically because of the role they gave to all the stakeholders - through empathy ("their net is wider and bigger in terms of their starting point") and co-creation ("how much you consult with the different stakeholders"). Designers' holistic perspective of services allowed them to develop new service propositions while clearly identifying what needed to be done such as applications, new products, new environments, communication, and who needed to be involved, such as different actors who were part of the service delivery, including the users of the service. By doing so, service designers engaged with everyone they needed to design for and translated the service proposition into an actual service experience.

\section{Being empathetic with all stakeholders}

Empathy, "a way of stepping into the customer's shoes," as many informants put it, was frequently underscored as a second key value of the service design ethos. In fact, as Charlotte, a service designer at Design Thinkers, explained, empathizing with all stakeholders involved in the service delivery was crucial:

I don't think you can be a service designer without some level of empathy not just for how customers are, but also for how people that deliver the services are. It's very, very humancentric.

Empathy was enacted by service designers through all three material practices. In particular, service designers explained that, during the research phase, empathy emerged through the collection of deep insights about users and service providers. Some informants contrasted 
empathic design research with traditional market research techniques used by management consultants, and marketers. Victor, senior service designer at Innovation, explained how empathy allowed him to establish trust with service users and, hence, to develop a richer understanding of their needs and contexts than what could be achieved via formal interviews or focus groups. He added that clients were often skeptical about the difference between market research as usually done by management consultants and marketers and empathic design research, but when presented with the actual findings, "They're often, like, 'Wow, this is totally different from what we would get from traditional [market] research."' The difference between the two types of research lay in the empathy informing design research, which is "much richer in terms of [service designers] generating ideas and thinking creatively around a problem.”

Therefore, conducting design research was described as the starting point of any project, as it provided an empathetic understanding of the context and needs of all stakeholders - both service users and providers - in line with their holistic interpretation of services. Throughout several projects aiming at redesigning service experiences at European airports, for instance, Strategic Design had a team of designers shadowing people, conducting in situ interviews, and mimicking airport experiences by adopting different roles (a mother with three kids vs. a frequent business traveller). Not only did they focus on the passengers, but they also tried to understand the constraints of their clients and other stakeholders through interviews, observations, and data analysis (reviewing the number of passengers, average check-in times, or logistics processes). For Nora, a management consultant who collaborated with service designers at Innovation on a hospital project, this empathic, user-oriented nature of service designers' work was notable. Reflecting on her own practice in comparison to her experience working with service designers, she emphasized service designers' ability to empathize with patients and other stakeholders such 
doctors, nurses, and hospital administration. She contrasted this with the values of management consultants, and noted that it was "a fantastic attribute that Innovation brings" to their clients. Similarly, Iris, a manager in a public transportation company who had worked with both service designers and management consultants, compared the way they worked:

Differently from management consultants, service designers wanted to genuinely understand the business, they didn't pretend to understand it but they wanted to learn and immerse themselves in it a lot more which I think was really important to me. Whereas often you'll have your slightly more stark consultants coming in saying, 'We know this, we understand your business, this is what we need to do.' Whereas [service designers] wanted to understand [...] what [our front line staff was] like, what would interest them, what would be the challenges and they really wanted to understand the role in more detail.

To fully empathize with the service context they aimed to design, service designers visualized the evidence collected and the insights generated during research through various visual displays, e.g., personas, journey maps, and service blueprints. These artifacts were displayed in service design studios. Studios were all open plan spaces featuring designers' sharing desks and collaborating over visual displays such as photos, Post-It notes, and sketches (see images 1 and 2). For instance, at Strategic Design, a firm we visited regularly, multiple projects' customer journeys and photos were pinned on the walls, and often two or three designers were discussing or brainstorming in front of these visuals (see images 3 and 4). These visuals represented and portrayed users in their usual contexts (i.e., from their own perspective instead of from designers' and service providers' perspective), thus facilitating an empathetic engagement of service designers with the users of the current and/or future service.

Visualizing users' practices and contexts also helped trigger empathy in the service providers, who were not always aware of the needs and practices of the service users. Hence, when meeting with clients after the research phase, service designers heavily relied on visuals. Several of our informants set up rooms with visuals to immerse the clients. Videos were also seen as powerful for creating empathy with the service users. In this respect, John, the project manager for Maya, 
an airline company that hired Ideate to redesign the ir customer experience, explained the role of visualization techniques in fostering the empathetic engagement of Maya senior management with the customer experience. Although Maya prided itself on its customer experience, findings from the design research showed that customers didn't like the long-haul flight experience. Helping Maya senior managers step into their customers' shoes, therefore, was important in persuading them to embark in the project. To do so, the Ideate team complemented the expected PowerPoint presentations with storybooks, photos, quotes, and an animated video of the customer journey. John noted that all the visuals used by Ideate were critical to persuading the executives about the issues Maya faced.

Insert images 1 to 4 about here

Informants further explained that helping people imagine services through prototyping also facilitated empathy by "making things [i.e., services] real" and promoting a better understanding of future services. Given the inherent intangibility of services, service designers" ability to "make things real" through the creation of tangible artifacts and by visually communicating ideas was often emphasized as fundamental to the service design process. For example, to test some of the food and beverage services created by Ideate and the Maya team, they experimented on real flights with regular boarding crew and observed how passengers reacted to each new service. John, the Maya project manager, noted that the company had not done prototyping before and were impressed: "It was such a powerful way of trying something out to see what it looks like." Ultimately, Maya implemented many innovative changes to services, equipment, processes and technology that they had developed working with Ideate. Ideate designers claimed that this "real 
life" prototyping not only allowed them to test, iterate, and refine the concept for themselves, but also provided a better understanding of the actual experience for their client. Therefore, prototyping was central to reaching a common understanding of the idea under development.

By embracing empathy through design research, visualization, and prototyping, Ideate service designers sharply demarcated their occupation from other non-design occupations, claiming that if, for example, management consultants were to work on the Maya project, they would focus on the analytics behind the services provided on long-haul flights to increase their operational efficiency and would in cost-cutting exercises instead of focusing of passengers' real needs and their service experience. Ideate's distinctive way of working was also highlighted by the Maya team who had never worked with service designers before. Because of their holistic approach, Ideate empathized with all stakeholders involved in the travel experience instead of focusing only on the passengers and the crew (as traditional designers would likely have done) and this led them to redesign more than the interior of the plane, which was the original brief of the Maya team. Ideate's holistic approach also went hand in hand with their co-creation effort that involved multiple stakeholders.

\section{Co-creating with all stakeholders to design new services}

Co-creating was a third core value of service designers' ethos, and it represented a major difference in the way they worked with respect to other design and non-design occupations. Cocreating involved anyone from staff, executives, or users working collaboratively to design and develop a new service. Robert, a principal at Managing Service Design, raised this point when he contrasted the way service designers versus advertising agencies interact with clients:

We met with [the client] constantly, you know, and synthesized [the main insights] with them, so that there wasn't this concept that it was Margot and I coming up with the bright ideas once a week that we came back and reported, which is a bit like the advertising agency model, that "you leave it to us, and we'll come back with three suggestions, and you pick the one you like." Instead, we engage them much more heavily. 
Our informants underscored how involving both clients and customers in the co-creation process was critical to their working methods and emphasized their role as facilitators. Many Touchpoint articles noted the importance of this role:

Our recommendation to Service Designers is to be aware of the essential role of facilitation for successful behavioral change. The role of designers as facilitators and communicators has been highlighted, particularly in the co-designing process of new services. ${ }^{14}$

Most informants also mentioned this new and essential facilitator role, noting that service design practices required people "[to do] away with the celebrity designer and the individual," according to Gideon, senior research fellow at a design school. Several remarked that a facilitator role was still quite unusual in many traditional design disciplines. In fact, the head of industrial design at a US-based design school argued that facilitation was not the role of a designer, and heavily criticized approaches to design that advocate co-creation.

Co-creation was also very specific to the nature of what service designers designed, namely services rather than products. This was clearly stressed by Nick, co-founder of Strategic Design:

In product design, you just design the product. But in service design, for the service to be sustainable, you also need to build the factory that is the organization and the organizational capability.

The importance of capability building for the service to be enacted "live" increased the need for engaging all actors in a holistic co-creation process.

Informants consistently referred to co-creation as something deeply rooted in the material practices performed by service designers. Design research, for example, provided insights and evidence that engaged stakeholders involved in co-creating the service: "We facilitate through our research and through our techniques to bring the voice of the user in," Charlotte, a principal at Design Thinkers, explained. Some research methods, such as design probes and journals, required the direct involvement of users and/or service providers in the research process.

\footnotetext{
${ }^{14}$ Touchpoint $2 \# 1$ - Service Design and Behavioural Change (Kindle Locations 1051-1052). Service Design Network. Kindle Edition
} 
Co-creating often involved facilitating workshops where users and service providers were invited to brainstorm and develop new ideas using evidence (e.g., personas, photos, and artifacts) collected during the design research phase. For example, service designers at Innovation working with a local government body to develop a platform of services aimed at addressing the social care needs of the elderly population of a London borough engaged in seven co-creation workshops involving charity organizations, district councils, local authorities, and health providers. During these workshops, service designers shared findings from ethnographic research as well as case studies on successful projects in other countries. Visualizing and prototyping were the main material practices that provided rules and context for engagement in the cocreation of new services. Visualizing ideas through sketching, customer journeys, and mapping helped participants build a shared understanding of the envisioned service by facilitating communication and supporting collective sensemaking. Workshop participants identified five principles that became the main components of the new service implemented by the council. Workshop participants praised the benefits of co-creation in terms of getting away from the "one-organization-knows-best" model to a "highly inclusive approach where all organizations have a role to play." Jono, the lead commissioner of the project, explained that he decided to work with service designers instead of management consultants because, "as a local authority, we saw co-production and stakeholders' engagement as our starting point, and service design was for us a specific process to do that."

Nora, the management consultant who worked with Innovation on the UK hospital project, explained the importance of co-creation. She recalled a client's comment during a co-creation workshop with about eighty participants, clinicians, and politicians:

I remember the sponsor coming up to me half way through, and he was really excited. And he said, 'You won't believe it,' he said. 'For the last two years I've been sitting next to these people. And they've been fighting, fighting me all the way, and talking about hospital closures. 
And yet we're sitting in this room now, and we're designing things together.' He said, 'This is the first time this has ever happened.' And it absolutely comes down to the tools and techniques and the style of the facilitation that service designers used.

Prototyping was a crucial practice during these co-creation workshops. Using artifacts such as paper, cardboard, Lego bricks, and Playmobils allowed participants to think with their hands, test ideas by getting other participants' input, and collaboratively develop ideas. For example, while working on a project to redesign public services for a council in London, Strategic Design organized a workshop where service designers, users and service providers worked in teams to co-create possible scenarios, and then prototyped these scenarios with Lego bricks (see images 57). The very simple prototypes supported the co-creation process because they helped participants articulate and discuss their ideas with others. Specifically, workshop participants could provide complementary insights about the context, needs, and potential resistance to the new services. All the clients we interviewed about service designers' work methods emphasized the use of prototyping and visualization techniques as crucial to collaboration and ideation during co-creation workshops.

Insert images 5-7 about here

Co-creating with all stakeholders, therefore, represents an important differentiating value of service designers' ethos. By enacting this value, service designers clearly set themselves apart from other occupations, such as marketers and management consultants, who might work on service innovation projects but with less collaboration and more of a focus on developing their "own" idea rather than co-creating with clients and users of the service. This difference was stressed by Zeynep, a senior strategy and business developer at a civil and social organization, who had worked with both management consultants and service designers: 
The experience is very different. [...] I suppose my most obvious reaction would be that [management consultants] tend to be far more one dimensional and far less dynamic. So they tend to be targeted at more senior stakeholders in an organization, and I think that they engage with an organization in a way that I think service designers don't. Service designers, because they use cocreation are far more enablers of change, and that they trust that the people it works with are the experts, and the people it works with are going to execute the change, and therefore the role of the service designer is to enable and guide that.

Moreover, expanding co-creation in line with their holistic approach also differentiated service designers from traditional design. While some traditional designers may co-create, they typically engage only users rather than all stakeholders and co-creation is not pro forma for all designers. As Katia, service designer at Island, remarked:

You need to work in partnership with your client. It's not that your client gives you a brief, and you go, okay, and you go away and you get on with your project work. It's not the, kind of, 'Mad Man' model of design where the agency knows best, and you will like what we show you because we know, because we're right.

To summarize, defining a new ethos and enacting it through material practices was imperative for allowing service designers to construct an occupational mandate and to differentiate themselves from other occupations. Although service designers' ethos was central in differentiating them from other occupations (i.e., claiming their ability to perform their work better than other occupations competing for the same clients), its values became meaningful when they were enacted through material work practices.

More importantly, service designers carved out a specific role for their occupation, defined by their ability to solve strategic and systemic problems by enacting material work practices in a way that reflected their ethos. This ethos, always embodied in material practices, was integral to defining the proper conduct and modes of thinking evoking service designers' occupational mandate. The intertwinement of values and practices, at the core of service designers' ethos, is what allowed service designers to differentiate themselves from other occupations.

\section{DISCUSSION AND CONCLUSIONS}


While previous research on occupational emergence has focused mostly on claiming or negotiating jurisdiction, we concentrate on the process by which members of a fledgling occupation, such as service design, created a sense of shared mission and carved out a mandate for themselves vis-à-vis other occupations. In this respect, we extend a small but vibrant body of interactionist research on occupations by showing how the development of the occupational mandate is grounded in the enactment of a new ethos, i.e., values enacted through work practices. In doing so, we depart from existing research focusing on occupations already established or sufficiently established to develop institutional support (e.g. Abbott, 1988; Chreim et al., 2007; Greenwood and Suddaby, 2006; Reay et al., 2006), and we try to understand the activities that practitioners of a fledgling occupation engage in before achieving such institutional support. In other words, we look at how emerging occupations face the challenge of achieving social recognition by developing an occupational mandate for their work.

This is particularly timely and important in the current work context, where the number of new occupations is growing (Watson, 2013). Service design belongs to the set of novel occupations that emerged when service and white-collar work became central to the economy (Blackler, 1995; Vallas and Beck 1996; Barley 1996). Our study allows us to unpack the occupational dynamics of the new economy by shifting attention from the field-level and institutional environment to the interactional level and the work practices performed by members of new occupations. We advance current understanding of how members of fledgling occupations manage to "develop the cultural footing necessary to claim that their activities are work, that they perform the work better than competitors, and that their skills warrant special status" (Nelsen and Barley, 1997: 621) by highlighting the role of the ethos - values enacted through practices - in the construction of an occupational mandate. 
We show how service designers' ethos was dynamically enacted vis-à-vis two other groups of occupations, designers on the one hand, management consultants and marketers on the other hand. Service designers' ethos includes three main values -holism, empathy and co-creation which were reinterpreted by service designers in order to better differentiate themselves. Originally, service designers aimed to differentiate themselves from designers as they desired their work to be more strategic and upstream than traditional designers and, thus, holism was crucial to the construction of their occupational mandate. However, to differentiate themselves from management consultants' and marketers' strategic approaches, they were also faithful to design values, such as empathy and co-creation, that they reinterpreted holistically to include all stakeholders involved in the service, and not only the users, as traditional designers tend to do. Moreover, empathy and co-creation also influenced the holistic perspective taken by service designers. Indeed, being holistic was more than taking a strategic or system view, which can be associated with management consultants, as such a view could potentially be quite top-down and disembodied. Because of their empathetic engagement with all stakeholders, service designers' holism was deeply grounded in specific uses and practices from different users in various contexts. Because of their belief in co-creation, service designers' view of holism aimed to set the stage for various co-creation activities to take place.

This paper, thus, makes two major contributions to the literature on occupations and work. First, it illuminates how values play a role in the construction of an occupational mandate, especially when skills and expertise are not the main differentiating factor. Second, it highlights the role of work practices in enacting an occupational mandate and suggests that the distinction between values and work practices is merely analytical. In an ethos, values and material work practices are intrinsically connected: material practices as enacted by service designers were 
"embodied values." While the ethos existed only as enacted in and through practice, material practices were differentiating only when they were enacted in a way congruent with service designers' ethos.

\section{The differentiating role of values in the construction of an occupational mandate}

Our study highlights that what really differentiates service designers from other occupations are their values or what Abbott (1988) defines as the subjective construal of the work. While Abbott (1988) acknowledges that values might help practitioners develop a feeling of distinctiveness, he also claims that, in the twentieth century, values played a decreasing role in legitimizing work domains. Among the armed forces, Abbott (1988: 191) quips, "only the Marines are still looking for a few good men," and he argues that occupations primarily leverage technical expertise and skill as sources of legitimacy. While he may be correct in asserting the declining importance of occupational claims based on broad moral character, we find that values are still, and may be increasingly, important sources of differentiation for nascent occupations. If we consider occupations as constituted of "sets of relationships that are social as well as technical" (Hughes, 1984: 294), and if members of an occupation "collectively . . presume to tell society what is good and right for it in a broad and crucial aspect of life" (Hughes, 1984: 288), it is essential that we understand the role of values in defining an occupational mandate.

Some studies (Barley, 1983; Nelsen and Barley, 1997; Arndt and Bigelow, 2005; Anteby, 2010) have started to emphasize the role of values in understanding distinctions between occupations. In line with these studies, we have found that values are critical to the construction and enactment of an occupational mandate. This is particularly important at the early stages of an occupation's development, when finding like-minded colleagues and developing a sense of shared mission and meaning is crucial (Bucher, 1962, 1988). Nascent occupations are not yet at 
a stage where they can use some of the legitimation strategies suggested by the literature on professions, such as closure of membership (Halpern, 1992; Begun and Lippincott, 1987), because they do not have access to the resources to enact them. However, they still aim to construct an occupational mandate. Therefore, our study casts light on the pre-institutionalization phase of new occupations, demonstrating that nascent occupations leverage values and practices as a legitimization strategy when they lack institutional means for supporting their jurisdiction.

Moreover, we show that values, as well as skills and knowledge, are essential in distinguishing work. This is particularly relevant when skills and expertise are not key differentiators between two groups, in both new or institutionalized occupations. Our findings show that service designers were not shy to admit that their work incorporates methods and tools from a variety of other occupations. As Steve the co-founder of Sustain and Grow explained, "[Service design] was really a combination of knowledge developed in different fields marketing, HCI, branding and so on. We took the best out of the fields we knew." In other words, service designers merged various practices to create their service design toolkit: borrowing some practices from designers (e.g. visualizing, prototyping), others from management consultants (e.g. strategic analysis, facilitation skills) and creating some specific tools like service ecosystem maps and experience prototypes. They incorporated these practices within a set of values that shaped their way of working. We might expect that members of emerging occupations who cannot solely rely on skills and technical expertise as sources of differentiation will take a similar approach to service designers' in developing their mandates, that is combining elements (methods, or tools, e.g.) from other occupations to define their practices in a way that is aligned with their unique set of values, framing how they work, which they see as the core differentiator for their occupational mandate. 
Sometimes even in institutionalized fields, groups of like-minded individuals with similar work interests and practices are not able to define a set of formal standards to support an occupational mandate. For example, Baszanger (1990) shows that, even in medicine, subspecialties are no longer clearly distinguishable by the work that they do. She describes the emergence of "doctors of pain": an occupation that draws on multiple subspecialties of doctors and other medical practitioners who treat chronic pain. This group of like-minded colleagues has a particular ethos around the treatment of chronic pain, which unites them, yet they are still divided by subspecialty. They have no recognizable occupational title or code, and struggle to be recognized by medical institutions in France. Zetka's study (2011) of the battle between gynaecologic oncologists and gynaecologic pelvic surgeons to be recognized as a subspecialty of American ob/gyn demonstrates a similar dynamic. While both occupations shared surgical skills and expertise, the pelvic surgeons' claims for jurisdiction were resisted because they presented their occupational mandate under a mechanical surgery ethos rather than a holistic, patientcentered, "obstetric point of view" (2011: 841). Hence, the oncologists' mandate was recognized not because of their skills and expertise but because of the values they stood for.

Similarly, members of occupations like executive coaching, psychotherapy, and workplace counseling come from different backgrounds and traditions and have slightly different tools and techniques. Yet, their methods are overlapping and all aim to assess individuals' behaviors and emotions in organizational contexts and to support them in reaching their goals. In this unclear and evolving occupational arena, the main boundary between these groups lays in their values: their general attitude towards clients and how they perceive their relationship to them. Values become particularly important as distinguishing elements in circumstances where the task or technology is less salient in the definition of occupations. As Damarin (2006) highlights in her 
study of web work, many emerging occupations do not hew to ideal-typical definitions but appear as broader and less uniform categories. Thus, what is distinct about web work is not workers' mastery of a set of digital skills needed to perform their tasks but its flexible and modular nature, involving changing combinations of multiple tasks and skills. In line with our findings, Damarin notes the loyalty of web workers to the value of "the Web as a community and a project" (2006: 457). We would expect that other new occupations which cannot distinguish themselves by task or technology would rely more on values as a source of differentiation and legitimation. Our study starts to explore the role of values in how service designers construct their occupational mandate, but more such studies are required, particularly because the boundaries between occupations are in constant flux and skills and knowledge may no longer be the main differentiating dimension. In this context, understanding how members of nascent occupations construct an occupational mandate in order to then develop legitimacy and institutional support proves particularly important to enrich current understandings of occupational dynamics.

\section{The intertwining of values and practices}

As noted by Bucher (1988: 134), "inquiry into the emergence of new occupations has focused on looking for 'causes." Most studies of emerging occupations indeed focus on the triggers that prompt the emergence of new occupations, highlighting the role of new technologies, skills, or organizational forms (Abbott, 1988; Zetka, 2003; Hughes, 1984; Bucher, 1988). Yet, as Bucher (1988) stresses, irrespective of what instigates their emergence, all occupations must go through a developmental process that always starts with "discovering colleagueship" (Bucher, 1988: 136) and constructing an occupational mandate that defines proper conduct, modes of thinking, and beliefs (Hughes, 1984). However, while highlighting the importance of this process, interactionist 
scholars have not unpacked how it actually happens. In this paper, we focus on the construction of a mandate, the values it involves, and its enactment in practice. Our study provides solid empirical ground for understanding how values and practices are recursively linked to each other in the enactment of an ethos.

Our findings on the role of ethos in the construction of service designers' occupational mandate suggests that future studies should not only concentrate on the triggers of emerging occupations such as technology and new skills, but also consider the social and cultural construction of the occupation through the values that its members refer to and, most importantly, enact in their work practices. Our analysis of service designers' ethos illustrates how values and practices are intrinsically intertwined. Values without "walking the talk" are but empty words; practices without a sense of mission and meaning can be reproduced by anyone. Service designers' occupation was distinguished not just by the set of practices they mastered, but also by their ability to discern how and when to use (and adapt) this set of practices for a specific project. This ability to choose the right set of practices in the service design repertoire (many of which were borrowed from other disciplines), as well as to apply them with a certain ethos, was a key differentiator for service designers. Hence, to become a service designer, mastering material work practices is not enough; one must also adopt the ethos that enables their successful use.

The role of practices as a key element in the construction of an occupational mandate provides an important contrast to the literature on professions' institutionalization (Abbott, 1988), which emphasizes the central role of official certification, formal education, and abstract knowledge in developing an occupation. Service designers' lack of abstract knowled ge and certification creates a lot of uncertainty about their skills. Service designers thus use their repertoire of work practices in their work, on their websites, and in their client presentations to demonstrate their skills and 
expertise. This also serves to reassure clients about the intangible aspects of the service design process. For example, successful service design projects imply mastery of specific practices, such as doing design research, visualizing and prototyping. Service designers claimed jurisdiction over those practices, as our informants illustrated, telling us that "this is designers' stuff." By demonstrating this use of practices to create a mandate, our findings support and build upon studies which show the importance of material practices enacted by members of established occupations who are trying to change or protect their jurisdiction (Anteby, 2010, Bechky, 2003, Zekta, 2003; Nelsen and Barley, 1997).

However, work practices, while important in the construction of service designers' occupational mandate, represent only one aspect of the occupational mandate. Hence, to become a service designer, mastering work practices is not enough. One could argue, for example, that you could just go to a service design consultancy's website and steal their methods or take a course in design thinking to become a service designer. In fact, our informants did not mind sharing the methods they used on a blog, a website or even in a workshop. For them, what was distinctive in their work was not their practices, but their ethos, i.e. how their values infused their work. This points to the intertwinement of practices and values, illustrating how "meanings and materiality are enacted together" (Orlikowski 2010: 135) in the construction of an occupational mandate. Galison (1999) makes a similar point about the intricate relationship between values and material practices in his study of scientific objectivity. Like service designers, laboratory scientists' moral and epistemological beliefs and technical practices emerged simultaneously. This was seen in the ways their inscriptions of findings in texts and images changed over time.

This comparison highlights a methodological contribution of our study. Values, by their very nature, are difficult to study, and exploring material practices and inscriptions may provide a 
fruitful entry point for these investigations, opening up new possibilities for research on occupational change. One way to deepen our understanding about the role of values in creating occupational legitimacy is to incorporate a richer understanding of work practices. As Nelsen and Barley (1997) note, for instance, occupations' early practitioners may not be very articulate and intentional in the construction of their mandate. Therefore, explicitly attending to their work practices provides a way to explore and unveil their values as well as the role that these values play in the construction of occupational legitimacy. Doing so would highlight the tensions and alignments between the public strategies and actions of occupations (Kronus, 1976; Halpern, 1992; Power, 1997; Suddaby and Greenwood, 2005) and the way they enact their values in everyday practice.

While extant research on occupations provides rich accounts of the jurisdictional strategies enacted by members of occupations that have already achieved institutional support, we know much less about the practices enacted by occupational members prior to this. Our exploration of service designers' ethos focuses attention on the importance of intertwined values and practices in the construction of an occupational mandate. Especially given the state of occupational flux in our current economy, new occupations cannot rely only on skills, expertise and technology for claims of legitimacy. As a result, defining, solidifying and maintaining an occupational jurisdiction might hinge on the ability of these occupations to differentiate their values and practices. Understanding the role of the ethos therefore provides complementary analytic leverage to unpack the complexity of occupational dynamics. 


\section{REFERENCES}

Abbott, A.

1988 "The System of Professions: An Essay on the Divisions of Expert Labor." Chicago: University of Chicago Press.

\section{Alvesson, $M$ and $M$. Robertson}

2006. "The Best and the Brightest: The Construction, Significance and Effects of Elite Identities in Consulting Firms." Organization, 13: 195-224.

Anteby, M.

2010. "Markets, Morals and Practices of Trade: Jurisdictional Disputes in the US Commerce in Cadavers." Administrative Science Quarterly, 55:606-638.

\section{Arndt, M. and B. Bigelow.}

2005. "Professionalizing and masculinizing a female occupation: The reconceptualization of hospital administration in the early 1900s." Administrative Science Quarterly, 50: 233-261.

\section{Barley, S. R.}

1983. "Semiotics and the study of occupational and organizational cultures." Administrative Science Quarterly, 28: 393-413.

\section{Barley, S. R.}

1986. "Technology as an occasion for structuring: evidence from observations of CT scanners and the social order of radiology departments." Administrative Science Quarterly, 31:78-108.

\section{Barley, S. R.}

1996. "Technicians in the Workplace: Ethnographic Evidence for Bringinng Work into Organization Studies." Administrative Science Quarterly, 41:404-441.

\section{Baszanger, I.}

1990 "Emergence d'un groupe professionnel et travail de légitimation: Le cas des médecins de la douleur." Revue française de sociologie, 31:257-282.

\section{Bechky, B. A.}

2003. "Object lessons: Workplace artifacts as representations of occupational jurisdiction." American Journal of Sociology, 109: 720-752.

\section{Bechky, B. A.}

2006. "Gaffers, Gofers, and Grips: Role-Based Coordination in Temporary Organizations." Organization Science, 17: 3-21.

\section{Bechky, B. A.}

2011. "Making Organizational Theory Work Institutions, Occupations, and Negotiated Orders." Organization Science, 22: 1157-1167.

\section{Begun, J.W., and R.C. Lippincott}

1987. The Origins of Interoccupational Conflict. Work and Occupations, 14(3): 368-386.

\section{Blackler, F.}

1995. "Knowledge, knowledge work and organizations: An overview and interpretation." Organization studies, 16: 1021-1046.

\section{Blumer, $\mathbf{H}$.}


1969. "Symbolic Interactionism: Perspective and Method." Englewood Cliffs, NJ: Prenticehall.

Brown, T.

2009. "Change by Design." HarperCollins, New York.

\section{Brynjolfsson E. and A. McAfee}

2012. "Race against the Machine: How the Digital Revolution Is Accelerating Innovation, Driving Productivity, and Irreversibly Transforming Employment and the Economy". Digital Frontier Press.

\section{Bucher, R., and A. Strauss}

1961. "Professions in process." American Journal of Sociology, 66: 325-334.

\section{Bucher, R.}

1962. "Pathology: A study of social movements within a profession." Social Problems, 10: 4051.

\section{Bucher, R.}

1988. "On the Natural History of Health Care Occupations." Work and Occupations, 15: 131147.

Chreim, S., B. E. Williams, and C. R. Hinings

2007. "Interlevel influences on the recognition of professional role identity." Academy of Management Journal, 50: 1515-1539.

Damarin, A. K.

2006. "Rethinking Occupational Structure: The Case of Web Site Production Work." Work and Occupations, 33: 429-463.

Davis, G.S. and J.A. Cobb.

2010. "Corporations and Economic Inequality around the World: The Paradox of Hierarchy". Research in Organizational Behavior 30:35-53

Davis, G. S.

2013 "Essays in the Earlier History of American Corporations". Cambridge: Harvard University Press.

\section{Dingwall, $\mathbf{R}$.}

1983. "'In the beginning was the work.' Reflections on the genesis of occupations." The Sociological Review, 31: 605-624.

Faulkner, R.

1978. "Swimming With Sharks: Occupational Mandate and The Film Composer in Hollywood." Qualitative Sociology, 1: 99-129.

Foucault, M.

1963/1989. "The Birth of the Clinic." London: Routledge.

Galison, P., 1999. "'Objectivity is Romantic", The Humanities and the Sciences, Occasional Paper, 47, ACLS Annual Meetings, Philadelphia, PA.

Glaser, B.G.,and A.L. Strauss

1967. "The Discovery of Grounded Theory." Aldine, New York. 
Goffman, E.

1983. "The interaction order: American Sociological Association, 1982 presidential address." American sociological review, 1-17.

\section{Greenwood, R. and R.Suddaby}

2006. "Institutional Entrepreneurship in Mature Fields: The Big Five Accounting Firms." Academy of Management Journal, 49: 27-48.

Gross, C. and A. Kieser

2006. "Are consultants moving towards professionalization?" In: Greenwood R and Suddaby R (eds) Professional Service Firms. Oxford: JAI Press.

Hall, P. M.

1972. "A symbolic interactionist analysis of politics." Sociological Inquiry, 42: 35-75.

\section{Halpern, S.A.}

1992. "Dynamics of professional control: Internal coalitions and crossprofessional boundaries." American Journal of Sociology, 97: 994-1021.

\section{Hollins, G., and B. Hollins}

1991. "Total Design: Managing the Design Process in the Service Sector." Philadelphia: Trans Atlantic Publications.

Hughes, E. C.

1958. Men and their work. Glencoe, IL: Free Press.

\section{Hughes E.}

1984. The Sociological Eye. New York: Transaction Publishers.

Kalleberg, A. L.

2011. Good Jobs, Bad Jobs: The Rise of Polarized and Precarious Employment Systems in the United States, 1970s-2000s. New York: Russell Sage.

\section{Kimbell, L.}

2011."Designing for Service as One Way of Designing Services," International Journal of Design, 5(2): 41-52.

\section{Kipping, M. and D. Saint-Martin}

2005. "Between regulations, promotion and consumption: Government and management consultancy in Britain". Business History, 47: 449-465.

\section{Kipping, M.}

2011. "Hollow from the start? Image professionalism in management consulting." Current Sociology, 59: 530-550.

\section{Kronus, C.L.}

1976. "The Evolution of Occupational Power An Historical Study of Task Boundaries between Physicians and Pharmacists." Work and Occupations, 3:3-37.

Lawrence, T.B.

2004. "Rituals and resistance: Membership dynamics in professional fields." Human Relations, 57: 115-143.

\section{Lincoln, Y., and E. Guba}


1985. 'Naturalistic Inquiry'. Newbury Park, CA: Sage Publications.

Locke, K. D.

2001. "Grounded theory in management research." Thousand Oaks, Calif.: Sage Publications.

Lusch, R., and S. Nambisan

2015. "Service Innovation: A service-dominant logic perspective." Management Information Systems Quarterly, 39: 155-171.

Mager, B.

2004 "Service design: A review." KISD, Köln.

McKenna, C. D.

2006. "The world's newest profession: management consulting in the twentieth century." New York: Cambridge University Press.

McMurray, R.

2011 "The struggle to professionalize: An ethnographic account of the occupational position of Advanced Nurse Practitioners." Human Relations, 64: 801-822.

Miles M.B., and H. Huberman

1994 “Qualitative Data Analysis : An Expanded Sourcebook” Sage Publications.

Moritz, S.

2005 "Service Design. Practical Access to an Evolving Field" Unpublished Masters thesis.

Nelsen, B.J., S. R. Barley.

1997. "For Love or for Money? Commodification and the Construction of an Occupational Mandate." Administrative Science Quarterly, 42: 619-653.

Power, M.

1997. "Expertise and the social construction of relevance: Accountants and environmental audit. Accounting." Organizations and Society, 22: 123-46.

Reay, T., K. Golden-Biddle, and K. German

2006. "Legitimizing a new role: Small wins and microprocesses of change." Academy of Management Journal, 49: 977-998.

Rothman, R. A.

1979 "Occupational Roles: Power and Negotiation in the Division of Labor." The Sociological Quarterly, 20: 495-515.

Sherman, R.

2010. "'Time Is Our Commodity': Gender and the Struggle for Occupational Legitimacy Among Personal Concierges." Work and Occupations, 37: 81-114.

Shostack, L. G.

1984. "Design Services that Deliver." Harvard Business Review, 133-139.

Spradley 1979

1979. "The ethnographic interview." Belmont, Calif.: Wadsworth, Cengage Learning .

\section{Strauss A.}


1978. "A social world perspective". In Studies in symbolic interactions. Greenwich Jai Press, 2 : $119-128$

\section{Strauss, A.L., J. M. Corbin}

1990. "Basics of qualitative research : grounded theory procedures and techniques." Newbury Park, Calif.: Sage Publications.

\section{Suddabby, R., and R. Greenwood}

2005. "Rhetorical Strategies of Legitimacy." Administrative Science Quarterly, 50: 35-67.

\section{Vallas, S. P., and J.n P. Beck}

1996. "The transformation of work revisited: The limits of flexibility in American manufacturing." Social Problems, 43: 339-61.

Van Maanen, J., Barley, S. R.

1984 "Occupational Communities: culture and control in organizations." Research in Organizational Behavior. 6: 287-365.

\section{Vargo, S. L. and R. Lusch}

2004. "Evolving to a new dominant logic for marketing." Journal of Marketing, 68: 1-17.

Vargo, S., Maglio P., and M. Akaka

2008. "On value and value co-creation: A service systems and service logic perspective." European Management Journal 26: 145-152.

Watson, A. L.

2013. "Implementing the 2010 Standard Occupational Classification in the Occupational Employment Statistics program." Monthly Labor Review, May 2013.

\section{Weber, M.}

1968. Economy and society: An outline of interpretive sociology. CA, University of California Press.

\section{Werr, A, and A. Styhre}

2003 "Understanding the ambiguous consultantom/science/article/p." International Studies of Management and Organizations, 32: 43ern.

\section{Zabuski, S. E., Barley, S. R.}

1997. You can't be a stone if you're cement: Revaluating the emic identities of scientists in organizations. Research in Organizational Behaviour. 19 361-404.

\section{Zetka, J. R.}

2003. "Surgeons and the Scope." Ithaca, N.Y., Cornell University Press.

\section{Zetka, J. R.}

2011. "Establishing specialty jurisdictions in medicine: the case of American obstetrics and gynaecology." Sociology of Health and Illness, 33: 837-852. 
Table 1. Interview summary table

\begin{tabular}{|c|c|c|}
\hline First Round (Feb-August 2010) & $\begin{array}{l}\text { Second Round (May } 2012 \text { - } \\
\text { August 2012) }\end{array}$ & Third Round (Sept - Dec. 2014) \\
\hline $\begin{array}{l}\text { John, cofounder of Sustain \& Grow, } \\
\text { and independent service designer }\end{array}$ & $\begin{array}{l}\text { Phoebe, service designer, Made } \\
\text { Together }\end{array}$ & $\begin{array}{l}\text { Mark, cofounder and director of } \\
\text { Sustain \& Grow }\end{array}$ \\
\hline $\begin{array}{l}\text { Mark, cofounder and director of } \\
\text { Sustain \& Grow }\end{array}$ & Kim, strategic and service designer & $\begin{array}{l}\text { Victor, senior service designer at } \\
\text { Innovation }\end{array}$ \\
\hline $\begin{array}{l}\text { Steve, cofounder and director of } \\
\text { Sustain \& Grow (2) }\end{array}$ & $\begin{array}{l}\text { Robert, principal and service } \\
\text { designer in a service design } \\
\text { consultancy }\end{array}$ & Emile, service designer, Innovation \\
\hline $\begin{array}{l}\text { Martin, service designer, Sustain \& } \\
\text { Grow }\end{array}$ & $\begin{array}{l}\text { Milena, assistant professor of } \\
\text { social innovation and service } \\
\text { design }\end{array}$ & Nora, management consultant \\
\hline Nick, cofounder, Strategic Design & $\begin{array}{l}\text { Kristen, service designer and } \\
\text { social innovator }\end{array}$ & $\begin{array}{l}\text { Ricardo, senior manager in a public } \\
\text { transportation company }\end{array}$ \\
\hline Erik, cofounder, Strategic Design & $\begin{array}{l}\text { Charlotte, principal and service } \\
\text { designer, Design Thinkers }\end{array}$ & $\begin{array}{l}\text { Iris, manager in a public transportation } \\
\text { company }\end{array}$ \\
\hline $\begin{array}{l}\text { Toby, senior service designer, } \\
\text { Strategic Design }\end{array}$ & Ashley, service design lead, Island & $\begin{array}{l}\text { Shak, director in a social care } \\
\text { nonprofit organization }\end{array}$ \\
\hline Luke, principal, Strategic Design (2) & Katia, service design lead, Island & $\begin{array}{l}\text { Manuela, manager in an engineering } \\
\text { and service company }\end{array}$ \\
\hline $\begin{array}{l}\text { Lindsey, service designer, Strategic } \\
\text { Design }\end{array}$ & $\begin{array}{l}\text { Nelson, service designerat an } \\
\text { innovation and web agency }\end{array}$ & $\begin{array}{l}\text { Dario, managing director of an } \\
\text { insurance company }\end{array}$ \\
\hline Daniel, principal, Strategic Design & $\begin{array}{l}\text { Gideon, senior research fellow at a } \\
\text { design school }\end{array}$ & Jono, director of a UK local authority \\
\hline $\begin{array}{l}\text { Don, service designer, Strategic } \\
\text { Design }\end{array}$ & $\begin{array}{l}\text { Elizabeth, service design } \\
\text { researcher and communication } \\
\text { strategy consultant }\end{array}$ & $\begin{array}{l}\text { Zeynep, senior strategy and business } \\
\text { developer at a civil and social } \\
\text { organization }\end{array}$ \\
\hline $\begin{array}{l}\text { Janelle, service designer, Strategic } \\
\text { Design }\end{array}$ & $\begin{array}{l}\text { Sherry, independent service design } \\
\text { strategist }\end{array}$ & $\begin{array}{l}\text { Gabriel, innovation and customer } \\
\text { experience lead at an international } \\
\text { bank }\end{array}$ \\
\hline $\begin{array}{l}\text { Victor, senior service designer, } \\
\text { Innovation }\end{array}$ & Ed, cofounder, People Focus & \\
\hline $\begin{array}{l}\text { Stephen, } \\
\text { cofounder and strategic director, } \\
\text { Future (2) }\end{array}$ & $\begin{array}{l}\text { Alan, head of service design } \\
\text { master's at the Royal College of } \\
\text { Art }\end{array}$ & \\
\hline $\begin{array}{l}\text { Josh, senior service designer, Future } \\
\text { (2) }\end{array}$ & $\begin{array}{l}\text { Sam, cofounder of a service design } \\
\text { consultancy }\end{array}$ & \\
\hline Juliette, cofounder and director, Spot & $\begin{array}{l}\text { Lucy, interaction and service } \\
\text { design consultant }\end{array}$ & \\
\hline Denis, cofounder and director, Spot & John, project manager, Maya & \\
\hline $\begin{array}{l}\text { Hannah, independent service designer } \\
\text { (former head of service design at a } \\
\text { major design and innovation } \\
\text { consultancy) }\end{array}$ & $\begin{array}{l}\text { Stephan, senior designer, Ideate } \\
\text { (lead designer on the Maya } \\
\text { project) }\end{array}$ & \\
\hline \multicolumn{3}{|l|}{$\begin{array}{l}\text { Bill, chief design officer, Design } \\
\text { Council }\end{array}$} \\
\hline \multicolumn{3}{|l|}{ Marlo, independent service designer } \\
\hline \multicolumn{3}{|l|}{$\begin{array}{l}\text { Alexis, founder and director, Beyond } \\
\text { Private }\end{array}$} \\
\hline 25 (21 informants) & 18 & 12 (10 informants) \\
\hline & & 55 (49 informants) \\
\hline
\end{tabular}


Table 2. Data sources and use

\begin{tabular}{|c|c|c|}
\hline Data source & Type of data & Use in the analysis \\
\hline \multicolumn{3}{|c|}{ Intensive Data Collection } \\
\hline Interviews & $\begin{array}{l}53 \text { in-depth interviews with: } \\
\text { (a) Service designers (b) Clients and management consultants }\end{array}$ & $\begin{array}{l}\text { Understand the development of the occupation of service design with a } \\
\text { focus on how service designers perceived their occupation, and gain a } \\
\text { deep understanding of their work practices by using evidence from } \\
\text { specific projects. } \\
\text { Identify the main values and material practices } \\
\text { Capture the clients and management consultants'perceptions about } \\
\text { service designers' work and enrich our emerging interpretations. }\end{array}$ \\
\hline Observations & $\begin{array}{l}\text { Field notes from visits to service design studios and from attending } \\
\text { brainstorming sessions and internal knowledge-sharing meetings }\end{array}$ & $\begin{array}{l}\text { Understand the use of the tools and methods used by service designers } \\
\text { Identify the three main material practices }\end{array}$ \\
\hline \multicolumn{3}{|c|}{ Ongoing Data Collection } \\
\hline Observations & $\begin{array}{l}\text { Field notes from attendance at: } \\
\text { (a) Social events organized by service designers, e. g. "Service } \\
\text { Design Thinks and Drinks," "Service Design Salon" } \\
\text { (b) Service design conferences, seminars, and workshops, e.g., } \\
\text { Service Design Conference, Global Service Jam) }\end{array}$ & $\begin{array}{l}\text { Familiarize with service designers and the service design community } \\
\text { Establish trust with informants } \\
\text { Collect stories related to service design projects that informants worked } \\
\text { on }\end{array}$ \\
\hline Archival data & $\begin{array}{l}\text { (a) } 18 \text { issues of Touchpoint (April } 2009 \text { - December 2014), the } \\
\text { international journal of service design published by the SDN. [In- } \\
\text { depth analysis of the first nine issues (volume 1:1 to volume 3:3)] } \\
\text { (b) LinkedIn Service Design Group (more than 9, } 500 \text { members) } \\
\text { since its creation in } 2010 \text { to December } 2014 \text {. We focused on the } 50 \\
\text { messages that were the most commented and / or liked. } \\
\text { (c) Press articles, corporate brochures, books, pamphlets, websites, } \\
\text { blogs, and internal and external presentations intended for specific } \\
\text { projects. }\end{array}$ & $\begin{array}{l}\text { Triangulate, support and integrate the evidence derived from interviews } \\
\text { and observations. }\end{array}$ \\
\hline $\begin{array}{l}\text { Informal } \\
\text { conversations }\end{array}$ & $\begin{array}{l}\text { Regular informal conversations with service designers, traditional } \\
\text { designers and design academics. }\end{array}$ & Share our provisional interpretations and gain further feedback. \\
\hline
\end{tabular}


Table 3. Representative quotes supporting our interpretations

\begin{tabular}{|c|c|c|c|}
\hline \multirow[t]{2}{*}{$\begin{array}{l}\text { Values of the } \\
\text { New Ethos }\end{array}$} & \multicolumn{3}{|l|}{ Service Designers' Practices } \\
\hline & Conducting design research & Visualizing & Prototyping \\
\hline $\begin{array}{l}\text { Being } \\
\text { empathetic }\end{array}$ & $\begin{array}{l}\text { We do everything [to gain empathy] from } \\
\text { observing people in their homes to taking } \\
\text { journeys, pretending to be different types of } \\
\text { user or personas. Going to an airport, for } \\
\text { example, and pretending to be partially } \\
\text { sighted or pretending to be with a family or } \\
\text { lost and then giving each other prompts like, } \\
\text { "You have five minutes to catch your flight" } \\
\text { or "You need to meet someone, but your } \\
\text { mobile phone doesn't work abroad." } \\
\text { Josh, senior service designer, Future } \\
\text { The only way I was going to really } \\
\text { understand this was by shadowing the } \\
\text { people, being a volunteer and doing the } \\
\text { jobs, and then speaking to people. And then } \\
\text { that way I could really understand what the } \\
\text { problems were. And from that I was able to } \\
\text { draw up a list of the different challenges that } \\
\text { were faced, and then be able to speak to the } \\
\text { volunteers and say: "Look, this is my point } \\
\text { of view. This is what I gained. What do you } \\
\text { think?" And although things were slightly } \\
\text { different, at the end of the day, they all kind } \\
\text { of boiled down to the same problems. } \\
\text { Kristen, service designerand social } \\
\text { innovator } \\
\text { This last week in this project we've done } \\
\text { with these hotels, we've been doing a } \\
\text { whistlestop tour of going around and having } \\
\text { tours of hotels, and just to be in there, it just }\end{array}$ & $\begin{array}{l}\text { I think we made } 117 \text { little vignettes and } \\
\text { sketches of all the possible Orange interactions } \\
\text { of the future. We made a massive sketchbook } \\
\text { for [the clients], and then we edited it down to } \\
\text { ten that we really brought to life. We spent a lot } \\
\text { of time creating stuff that felt like it really } \\
\text { existed. That's why the project was called } \\
\text { Tangible Evidence of Orange's Future. } \\
\text { John, cofounder, Sustain \& Grow } \\
\text { It's all very visual, and that helps us to map } \\
\text { stuff and understand it. It's important to clients } \\
\text { because it is... again, it's inspirational to them, } \\
\text { it helps them to make connections, it's } \\
\text { enjoyable. They like to see . . they don't like } \\
\text { seeing PowerPoint slides and words; they can't } \\
\text { get it. They're visual people, too ... They love } \\
\text { it to see their ideas brought to life. And then, } \\
\text { again, when you're going out to customers, it's } \\
\text { easy for them to see and understand. } \\
\text { Nick, cofounder, Strategic Design } \\
\text { I think one of the more powerful ways is to ... } \\
\text { When you're first presenting the proposition, } \\
\text { the principles will be beneath there. I thin k one } \\
\text { of the most powerful ways is to just bring back } \\
\text { the actual user footage and the research. If you } \\
\text { have a film where somebody's saying, I just } \\
\text { feel that in my local co mmun ity I can't say the } \\
\text { things I want to say, but I want to make a } \\
\text { difference and I want to make things better, but } \\
\text { I don't seem to have anywhere to say these }\end{array}$ & $\begin{array}{l}\text { So prototyping propositions means we've } \\
\text { got a bunch of things, and [the clients and } \\
\text { the users] can look at them and go: "Oh, I } \\
\text { get that," or you can say something like: } \\
\text { "Well, how does it work?" And they go: } \\
\text { "Oh yes, well, what it does is it does this } \\
\text { and that." Even though you haven't written } \\
\text { it. But you're starting to get them to reveal } \\
\text { stuff. } \\
\text { Juliette, cofounder, Spot } \\
\text { So as soon as you have an idea for a service } \\
\text { design project like: "I really think we can } \\
\text { improve the experience of standing in this } \\
\text { queue," in order to better articulate that } \\
\text { idea you have to create props, you have to } \\
\text { create stuff. You have to create all the } \\
\text { ephemera that live around it so that you can } \\
\text { get a sense of the mood and the feel of that } \\
\text { experience as a client, as a stakeholder, so } \\
\text { that you have things to talk about, so that } \\
\text { you have things to share. } \\
\text { Janelle, service designer, Strategic Design } \\
\text { The idea of showing a rough model before } \\
\text { the thing's finished. They don't finish the } \\
\text { thing and then try and sell it, they try it out } \\
\text { with you to get feedback. So, it's a } \\
\text { sophisticated trial and error process of } \\
\text { learning that's the difference. } \\
\text { Denis, cofounder, Spot }\end{array}$ \\
\hline
\end{tabular}




\begin{tabular}{|c|c|c|c|}
\hline & $\begin{array}{l}\text { makes it so much .... you could have read a } \\
\text { report about what happens, but, actually, it's } \\
\text { not until you see it and experience it that } \\
\text { you actually begin to own it and understand } \\
\text { it. } \\
\text { Nick, cofounder, Strategic Design }\end{array}$ & $\begin{array}{l}\text { things, that's really important. That's your user } \\
\text { saying things. } \\
\text { Josh, senior service designer, Future }\end{array}$ & \\
\hline $\begin{array}{l}\text { Taking a } \\
\text { holistic } \\
\text { approach }\end{array}$ & $\begin{array}{l}\text { One of the reasons we go out into the field } \\
\text { and research things and bring back artifacts, } \\
\text { evidence, photos, videos, scripts, is to be } \\
\text { able to share that with the team, and we'll } \\
\text { often map all of that kind of stuff on some } \\
\text { kind of journey so that you can understand } \\
\text { what is happening, where it's happening, but } \\
\text { most importantly when it's happening, } \\
\text { because the thing about services, yes, they're } \\
\text { often intangible, but they also take place } \\
\text { over time so that the time dimension is } \\
\text { incredibly important. } \\
\text { Luke, service design principal, Strategic } \\
\text { Design } \\
\text { [when referring to the research phase of a } \\
\text { project with a broadcasting company] So we } \\
\text { look at all the research that we've done on } \\
\text { their audiences, we look at their strategies, } \\
\text { the paper documents they have for the future } \\
\text { of the network. At the start we have this } \\
\text { orientation phase that is always about using } \\
\text { the research to develop a bigger point of } \\
\text { view or a bigger perspective on what's the } \\
\text { current situation with your network, how do } \\
\text { you perceive it to be? How do you perceive } \\
\text { your audience to be, what are their issues, } \\
\text { their needs; what's the core offering of your } \\
\text { network and what are the service qualities } \\
\text { that help to show that offering to the } \\
\text { audience? } \\
\text { Lindsey, service designer, Strategic Design }\end{array}$ & $\begin{array}{l}\text { One of our expertise as service designers is that } \\
\text { we can visualise, and we have a lot of emphasis } \\
\text { on the visualisation of the system that they're } \\
\text { working with in, to help them [the clients] see } \\
\text { things that they might not necessarily be able to } \\
\text { see from within the system, so the visualisation } \\
\text { and the artefact does become really important. } \\
\text { Robert, service design principal } \\
\text { [when talking about the importance of } \\
\text { visualizing a service system] But whether that } \\
\text { be mapping out a route or a journey or a } \\
\text { conceptualmodel or a map, they all serve to } \\
\text { gain and help understanding about the entire } \\
\text { service system. In the same way that metaphors } \\
\text { can explain a complex viewpoint or a complex } \\
\text { problem, it [visualizing] is that hook, those } \\
\text { visual stories help you understand what it is that } \\
\text { you're trying to achieve. Which is why, you } \\
\text { know, you might have KPIs or you might have } \\
\text { use cases, but when you bring it to life with user } \\
\text { journeys, that's when you can start to see how } \\
\text { it's working, and maybe challenge it. } \\
\text { Katia, service design lead, Island } \\
\text { Those who are doing it best have had the } \\
\text { schematic thinking, system thinking aug mented } \\
\text { by a way to visually extract that (...) I do think } \\
\text { that one of the important differentiating } \\
\text { character aspects for anyone with design in their } \\
\text { name is that you do need to be able to leverage }\end{array}$ & $\begin{array}{l}\text { When we prototype a service, we need to } \\
\text { understand how the [whole service] system } \\
\text { might be in order to create that credit card } \\
\text { for examp le; and I need to be able to draw } \\
\text { information from multiple elements [of the } \\
\text { system] in order to deliver on the } \\
\text { experience. The interesting thing about } \\
\text { prototyping services is actually building in } \\
\text { services holistically, which most service } \\
\text { organisations still don't do, because of the } \\
\text { silos } \\
\text { Hannah, independent service designer } \\
\text { I can explain something to you, but if I can } \\
\text { show you and you can see it, you'll get it } \\
\text { quicker, easier and it'll hold it in your } \\
\text { mind. Because if you're talking about an } \\
\text { intangible thing such as a service system, } \\
\text { you need to make it tangible in some way, } \\
\text { and especially if it involves different } \\
\text { people and processes and stuff. } \\
\text { Katia, service design lead, Island } \\
\text { I then get stuck into actually making that } \\
\text { happen from a business perspective and an } \\
\text { experiential perspective, and ends up in } \\
\text { going right the way through to prototypes } \\
\text { and specification documents and stuff like } \\
\text { that. } \\
\text { Nick, cofounder, Strategic Design }\end{array}$ \\
\hline
\end{tabular}




\begin{tabular}{|c|c|c|c|}
\hline & $\begin{array}{l}\text { It never really appealed to me as much as } \\
\text { being able to think about your whole } \\
\text { experience and to be (...) saying, I will } \\
\text { speak for these people. You're kind of an } \\
\text { unelected representative. There's a group of } \\
\text { users and you're the person who's fighting } \\
\text { their cause but at the same time you're } \\
\text { working for a client, whether they be a } \\
\text { council or a s mall business or a big } \\
\text { business. So, sometimes there's a } \\
\text { disagreement because you have to say, I } \\
\text { know what you're providing but your users } \\
\text { want something different, they're not } \\
\text { satisfied with it, they want this or that. } \\
\text { Josh, senior service designer, Future }\end{array}$ & $\begin{array}{l}\text { not just words but visual thinking in order to } \\
\text { explain. } \\
\text { Lucy, service design consultant and design } \\
\text { strategist }\end{array}$ & \\
\hline Co-creating & $\begin{array}{l}\text { We facilitate [co-creation workshops] } \\
\text { through our research and through our } \\
\text { techniques to bring the voice of the user } \\
\text { in ... } \\
\text { Charlotte, service design principal, Design } \\
\text { Thinkers } \\
\text { When you're going out into the field and } \\
\text { you're talking to a customer, you need to } \\
\text { talk in their language so you really have to } \\
\text { be multilingual in that respect. The designer } \\
\text { is a facilitator of the [co-creation] process in } \\
\text { terms of a facilitator can't just go up there } \\
\text { and browbeat everybody into how they } \\
\text { understand things. } \\
\text { Charlotte, service design principal, Design } \\
\text { Thinkers } \\
\text { We developed a package of "auto- } \\
\text { ethnographic video probes" that we gave to } \\
\text { the participants during a workshop. The } \\
\text { package included a small USB video } \\
\text { camera, with which we asked participants to } \\
\text { record film clips over a two-week period. }\end{array}$ & $\begin{array}{l}\text { In the last [co-creation workshop] I worked on, } \\
\text { we came up with a series of photographs and a } \\
\text { series or words to help prompt people to think } \\
\text { about who it was they were talking about; so } \\
\text { you could either give them a photograph of a } \\
\text { famous person, or someone they could re late to, } \\
\text { that makes them think about their service in a } \\
\text { different way, or put themselves in someone } \\
\text { else's shoes. And that type of thing is quite } \\
\text { successful. Or you know, or get them to think } \\
\text { about the situation that you're talking about, } \\
\text { from someone else's point of view. } \\
\text { Kristen, service designerand social Innovator } \\
\text { We just talk about sketches, and we teach our } \\
\text { clients to sketch. We do very quick workshops } \\
\text { to break their fear of drawing and then we get } \\
\text { them involved. We have these little basic } \\
\text { templates as well, so we have people at a table } \\
\text { talking with outline drawings for them to fill in } \\
\text { or catch them holding a mobile phone. So, if } \\
\text { they're really nervous it's not totally blank } \\
\text { sheets of paper. }\end{array}$ & $\begin{array}{l}\text { And then the whole process is extremely } \\
\text { collaborative. So there's this ... the work } \\
\text { that we're doing with Eurostar, again, a lot } \\
\text { of front-end research, a lot of journey } \\
\text { mapping, figuring out what the important } \\
\text { things were to their passengers and then } \\
\text { working ... going through a series of co- } \\
\text { creation workshops with staff and } \\
\text { passengers to explo re how to actually } \\
\text { improve things, so making it very . . so } \\
\text { we do a lot of gaming, I think, to help to } \\
\text { create things. So desktop prototyping, help } \\
\text { with trying to explore scenarios." } \\
\text { Nick, cofounder, Strategic Design } \\
\text { When I did the Inspire Foundation piece of } \\
\text { work, what we ended up doing was a series } \\
\text { of workshops where people would take the } \\
\text { principles of the strategy, and then apply it } \\
\text { to their area of work, and generate their } \\
\text { own ideas and their own draft pieces of } \\
\text { content, and prototype what thecontent and } \\
\text { the service would look like on }\end{array}$ \\
\hline
\end{tabular}




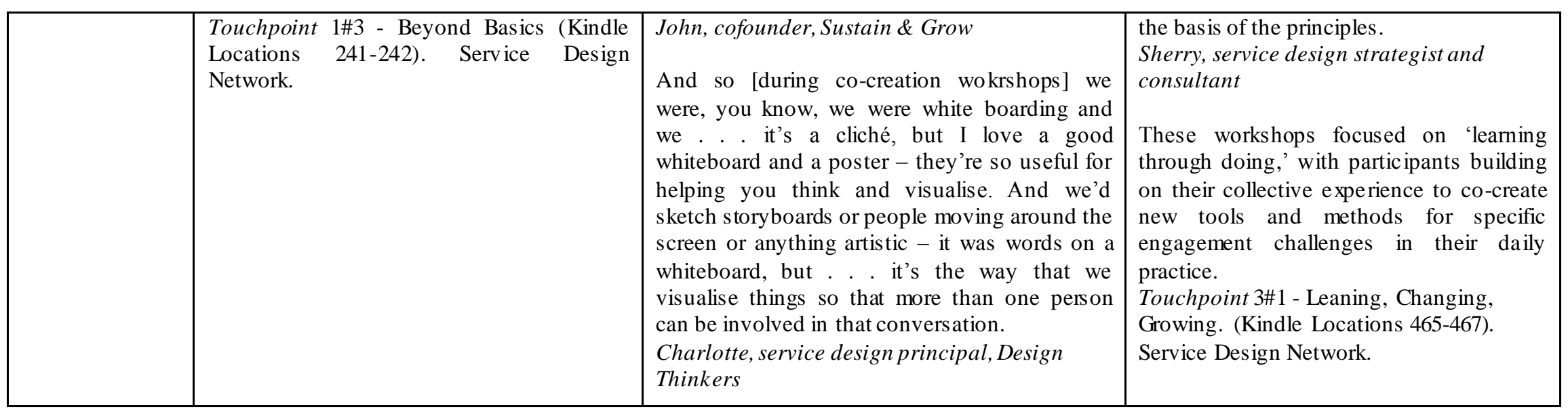


Images 1 and 2: Pioneer studio: post-its and visuals from current projects on the walls

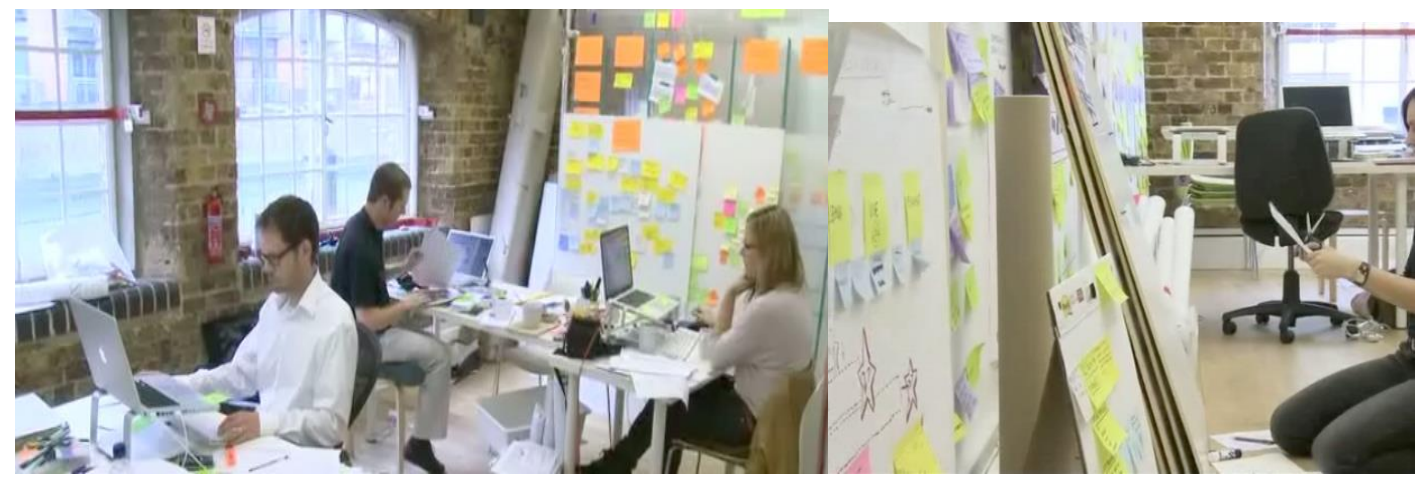

Images 3 and 4: Mapping the journey

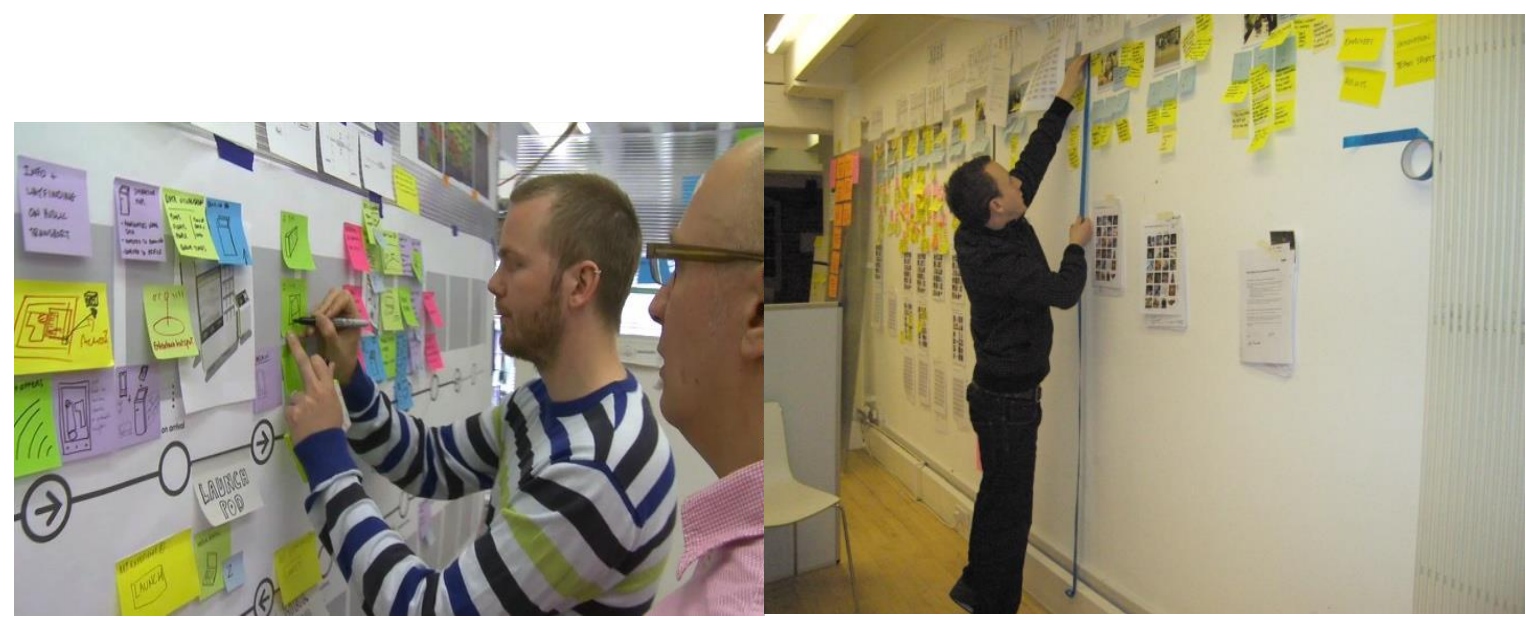

Images 5, 6, and 7: Co-creation sessionorganized by Strategic Design
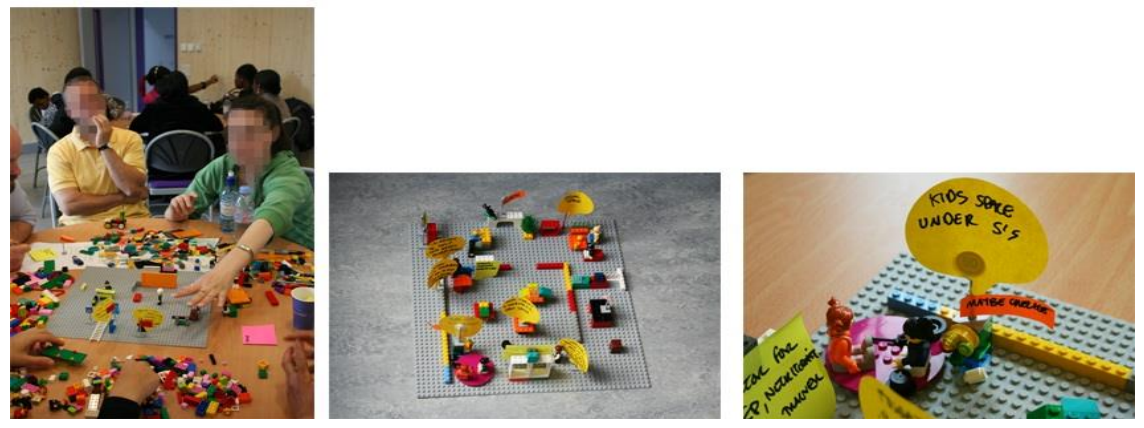


\section{Appendix}

\section{Table 1. List of the tools used by service designers}

\begin{tabular}{|c|c|c|}
\hline Name & Description & Use \\
\hline Shadowing & $\begin{array}{l}\text { Shadowing involves researchers immersing } \\
\text { themselves in the lives of customers, front-line } \\
\text { staff, or people behind the scenes in order to } \\
\text { observe their behaviours and experiences, } \\
\text { through videos, pictures, notes, etc. }\end{array}$ & $\begin{array}{l}\text { Shadowing is used to allow designers to } \\
\text { identify when, how, and why problems arise } \\
\text { during a customer experience and to develop } \\
\text { empathy for how users experience the service. } \\
\text { By doing so, it provides a deep understanding } \\
\text { of the real-time interactions that take place } \\
\text { between the various groups and touchpoints } \\
\text { involved. }\end{array}$ \\
\hline $\begin{array}{l}\text { Contextual } \\
\text { interviews }\end{array}$ & $\begin{array}{l}\text { Contextual interviews are conducted with } \\
\text { customers, staff, and other relevant } \\
\text { stakeholders within the environment in which } \\
\text { they interact with the service. }\end{array}$ & $\begin{array}{l}\text { Contextual interviews are used to help the } \\
\text { interviewees remember the specific details that } \\
\text { usually get lost in traditional focus group } \\
\text { settings. They allow researchers to gain a deep } \\
\text { understanding of the social and physical } \\
\text { environment surrounding the service, which } \\
\text { helps generate a more holistic understanding. }\end{array}$ \\
\hline $\begin{array}{l}\text { Design } \\
\text { Probes }\end{array}$ & $\begin{array}{l}\text { Design probes (sometimes also called cultural } \\
\text { probes) are information gathering packages, } \\
\text { usually given by the design team to users to } \\
\text { record aspects of their lives for a prolonged } \\
\text { period of time. The design probe may include } \\
\text { diaries, question cards, postcards, disposable } \\
\text { cameras, or other tools for mapping and } \\
\text { drawing. }\end{array}$ & $\begin{array}{l}\text { Based around the principle of user- } \\
\text { participation via self-documentation, design } \\
\text { probes are used in the design research phase to } \\
\text { generate personal insights directly by the users. } \\
\text { They allow to unravel people's beliefs and } \\
\text { desires, as well as to create detailed accounts of } \\
\text { people's lives. By doing so, they allow } \\
\text { designers to understand users' perspective } \\
\text { "first hand" and to engage users in the research } \\
\text { and indirectly in the design process. }\end{array}$ \\
\hline Personas & $\begin{array}{l}\text { Personas are fictional profiles, developed as a } \\
\text { way of representing a particular group of users } \\
\text { based on their shared interests. They represent } \\
\text { a character with which client and service } \\
\text { design team can engage. They are created by } \\
\text { collating research insights into common- } \\
\text { interest groupings that are then developed into } \\
\text { workable characters. Different techniques- } \\
\text { from visual representations to anecdotal } \\
\text { profiles, - can be used to bring these characters } \\
\text { to life. }\end{array}$ & $\begin{array}{l}\text { Personas provide a range of different } \\
\text { perspectives on a service, allowing service } \\
\text { design teams to define and engage the different } \\
\text { groups that may exist within their target } \\
\text { market. Personas shifts focus away from } \\
\text { demographics towards the needs of real } \\
\text { customers. }\end{array}$ \\
\hline $\begin{array}{l}\text { Stakeholder } \\
\text { maps }\end{array}$ & $\begin{array}{l}\text { Stakeholder maps are visuals representations of } \\
\text { the various groups involved with a particular } \\
\text { service and the relationships among them. They } \\
\text { are first created by compiling a complete list of } \\
\text { all the stakeholders and then identifying and } \\
\text { visually representing how they are related to } \\
\text { each other and how they interact with each } \\
\text { other. }\end{array}$ & $\begin{array}{l}\text { The overview provided by stakeholder maps is } \\
\text { a way to visually highlight the issues } \\
\text { concerning each stakeholder group so that the } \\
\text { service provider can deploy their resources } \\
\text { more effectively when responding to problems } \\
\text { and expanding their service. }\end{array}$ \\
\hline $\begin{array}{l}\text { Journey } \\
\text { maps }\end{array}$ & $\begin{array}{l}\text { Journey maps (also called customer journey or } \\
\text { experience journey maps) are visualizations of } \\
\text { a service user's experience. The touchpoints } \\
\text { where users interact with the service are used to } \\
\text { construct a journey based upon their }\end{array}$ & $\begin{array}{l}\text { By providing a representation of the user's } \\
\text { experience and of the factors influencing it } \\
\text { (e.g., behaviors, emotions, expectations, etc.), } \\
\text { customer journey maps enable the } \\
\text { identification of both problems and }\end{array}$ \\
\hline
\end{tabular}




\begin{tabular}{|c|c|c|}
\hline & $\begin{array}{l}\text { experience. The journey details the services } \\
\text { interactions and the emotions typically } \\
\text { experienced by users. }\end{array}$ & $\begin{array}{l}\text { opportunities for innovation. These visual } \\
\text { representations make it possible to compare } \\
\text { different users' experiences and to facilitate a } \\
\text { holistic experience of users' whole journey. }\end{array}$ \\
\hline $\begin{array}{l}\text { Service } \\
\text { blueprints }\end{array}$ & $\begin{array}{l}\text { Service blueprints are a way to specify and } \\
\text { detail each aspect of a service through a visual } \\
\text { schematic representation of the perspectives of } \\
\text { users, service providers, and other relevant } \\
\text { parties. They are produced collaboratively by } \\
\text { bringing together the various departments or } \\
\text { teams (often during co-creation workshops ) } \\
\text { that exist within the organization of the service } \\
\text { provider,. }\end{array}$ & $\begin{array}{l}\text { Service blueprints are used to identify the } \\
\text { crucial areas of a service, as well as areas of } \\
\text { overlap and duplication. They promote co- } \\
\text { operation and teamwork and help the service } \\
\text { provider coordinate people and resources. }\end{array}$ \\
\hline Storyboards & $\begin{array}{l}\text { Storyboards are series of drawings or pictures } \\
\text { that visualize a particular sequence of events } \\
\text { (e.g., a common situation where a service is } \\
\text { used, the hypothetical implementation of a new } \\
\text { service prototype). Storyboards are usually } \\
\text { constructed using the comic-strip format in } \\
\text { which designers create a series of illustrations } \\
\text { that tell the story of the situation being } \\
\text { examined. }\end{array}$ & $\begin{array}{l}\text { Service designers use storyboards to tell stories } \\
\text { about user experiences and to convey the key } \\
\text { aspects of a service. They are a type of rapid } \\
\text { prototype used to provoke mean ingful analysis, } \\
\text { spark discussions about problems, and possible } \\
\text { solutions among the design team and between } \\
\text { the team, users, and clients. }\end{array}$ \\
\hline $\begin{array}{l}\text { Design } \\
\text { scenarios }\end{array}$ & $\begin{array}{l}\text { Design scenarios are detailed hypothetical } \\
\text { stories, created to explore a particular aspect of } \\
\text { a service offering. Design scenarios can be } \\
\text { presented using plain text, storyboards, or even } \\
\text { videos. Research insights are used to construct } \\
\text { a plausible situation around which the scenario } \\
\text { can be based. Personas can be incorporated } \\
\text { within the scenario in order to focus the } \\
\text { situation around a clearly defined character. }\end{array}$ & $\begin{array}{l}\text { Design scenarios can be used in almost any } \\
\text { stage of a service design project, as they help } \\
\text { review, analyze, and understand the driving } \\
\text { factors that define a service experience. They } \\
\text { are often the results of co-creation workshops. }\end{array}$ \\
\hline $\begin{array}{l}\text { Experience } \\
\text { prototypes }\end{array}$ & $\begin{array}{l}\text { Experience prototypes are simulation of service } \\
\text { experiences. They usually take the form of } \\
\text { mock-ups of the service system. They can vary } \\
\text { in terms of tone and complexity from in formal } \\
\text { "role play"-style conversations to more detailed } \\
\text { full scale recreations involving user } \\
\text { participation, props, and physical touchpoints. }\end{array}$ & $\begin{array}{l}\text { Experience prototypes help service designers } \\
\text { generate a deep understanding of a service } \\
\text { based on "learning by doing," create tangible } \\
\text { evidence on which solutions can be founded, } \\
\text { and iterate design solutions, as they can be } \\
\text { used to quickly test and refine ideas. }\end{array}$ \\
\hline
\end{tabular}

